\title{
Reconstructing marine life-history strategies of wild Atlantic salmon from the stable isotope composition of otoliths
}

\author{
N. N. Hanson ${ }^{1, *}$, C. M. Wurster ${ }^{2}$, EIMF$^{3}$, C. D. Todd ${ }^{1}$ \\ ${ }^{1}$ Scottish Oceans Institute, University of St Andrews, St Andrews KY16 8LB, UK \\ ${ }^{2}$ School of Earth and Environmental Science, James Cook University, PO Box 6811, Cairns, Queensland 4870, Australia \\ ${ }^{3}$ Edinburgh Ion Microprobe Facility (EIMF), School of GeoSciences, University of Edinburgh, Kings Buildings, \\ West Main Road, Edinburgh EH9 3JW, UK
}

\begin{abstract}
Long-term declines in abundance of wild Atlantic salmon Salmo salar, L. have been linked to reductions in marine survivorship, and recent reductions in growth condition (a measure of fish quality) have been correlated to increased mid-winter sea-surface temperature anomalies in the eastern North Atlantic. Establishing a causal link between marine climate and salmon somatic condition is difficult without at-sea measurements of environmental and biological parameters, but electronically tagging these animals to obtain this information is also difficult and costly. The stable isotope composition of oxygen and carbon in the sequential layers of salmon otoliths can provide a basis for retrospective studies of the thermal, metabolic and dietary histories of individual fish. We used high resolution $\delta^{18} \mathrm{O}$ and $\delta^{13} \mathrm{C}$ profiles obtained using secondary ion mass spectrometry to compare the marine thermal and metabolic behaviour of 1 sea-winter return-migrant adult salmon. Seasonal and ontogenetic patterns in $\delta^{18} \mathrm{O}$ and $\delta^{13} \mathrm{C}$ values dominated isotope variation, although there were marked differences between individual profiles, indicating the potential for large differences in individual migration routes. There was no significant relationship between isotope variation and adult condition. Constructed thermal profiles provided plausible data, but the present uncertainty in otolith thermometry parameters for an openocean fish such as Atlantic salmon preclude firm conclusions based on these estimates. Marine life-history variation in otolith $\delta^{13} \mathrm{C}$ is likely driven by ontogenetic changes, both in diet and metabolism with size. A marked and rapid decrease in the $\delta^{13} \mathrm{C}$ values of some fish in the last month(s) of the marine migration could be an indicator of physiological changes occurring during the homing migration.
\end{abstract}

KEY WORDS: Atlantic salmon $\cdot$ Migration $\cdot$ Isoscape $\cdot$ Tracking $\cdot$ Condition factor $\cdot$ Metabolism

\section{INTRODUCTION}

The wild Atlantic salmon Salmo salar, L. is an important commercial and cultural species throughout its geographic distribution. Whereas most high seas fisheries have been curtailed or closed over the last 3 decades, coastal and freshwater fisheries still operate in many countries. Despite the reduction in exploitation both at sea and in freshwater, many stocks remain at reduced reproductive capacity (ICES 2010). In particular, the estimated pre-fishery abundance and spawning escapement of southern European stocks (originating from the British Isles, France, Spain and south/west Iceland) are approaching conservation limits, and there is growing recognition that a major driver of these declines is a reduction in marine survival (ICES 2008, Todd et al. 2008, Friedland et al. 2009, ICES 2010). 
Atlantic salmon are anadromous fish, emerging from gravel as alevins in freshwater in early spring; the precise timing depends upon the temperature and the rate of development of the eggs. Juveniles typically spend 1 to $5 \mathrm{yr}$ feeding on macroinvertebrates before undergoing smoltification and migration to sea. At sea, they may spend one (1 sea-winter, 1SW) or multiple (multi-sea-winters) years feeding on crustaceans, squid and fish in the sub-Arctic waters of the North Atlantic before returning to their natal rivers to spawn (Jacobsen \& Hansen 2000, Haugland et al. 2006, Rikardsen \& Dempson 2011). Recent decreased marine survival may result from high-seas exploitation, but, given the reduction in marine fishing pressure, other mechanisms are likely to be operating. Large-scale changes in the distribution and phenology of plankton species in the eastern North Atlantic over the past 3 decades have been connected with ocean climate change (Beaugrand et al. 2002, Beaugrand \& Reid 2003, Richardson \& Schoeman 2004); such shifts also could be implicated in reduced marine survival of salmon migrating to and from the Norwegian Sea (Beaugrand \& Reid 2003).

Todd et al. (2008) reported recent declines in length, weight and somatic growth of wild 1SW Atlantic salmon returning to Scottish rivers between 1993 and 2006. Using stock-specific length/weight regression equations to estimate the condition factor of individual fish and entire annual cohorts, and by linking these estimates to tissue lipid content, they showed a highly significant and progressive reduction in mean body condition and fat reserves of returning $1 \mathrm{SW}$ salmon. The driver appears to be an indirect influence of recent ocean warming on the availability of prey. This qualitative assessment of adult health of mixed stocks immediately prior to freshwater re-entry for spawning may be of more concern to salmon managers than are the declines in pre-fishery abundance and spawning escapement, because of its implications for the ability of salmon to successfully complete freshwater migration and spawn.

Whilst Todd et al. (2008) and others (Bacon et al. 2009, Friedland et al. 2009, Friedland \& Todd 2011) have recognized the likely contribution of marine climate changes to the reduction in abundance and growth success of $1 \mathrm{SW}$ stocks of wild Atlantic salmon, there is a dearth of empirical information regarding the specific marine migration trajectories of wild stocks. The inability to retrospectively study the environmental conditions actually experienced by salmon in the North Atlantic has made it difficult to identify seasonal times and regions of particular concern. Tracking marked or individual salmon at sea is very expensive and challenging; catch rates and tag returns often are low (Anonymous 2010) and, until comprehensive genetic databases are created, stock identification is constrained to large regions of the North Atlantic (e.g. North American versus European stocks) (Dempson et al. 2009). In this regard, sampling individuals from coastal fisheries for monitoring salmon health has 4 major advantages; first, it is relatively inexpensive compared to at-sea surveys. Second, regional provenance or specific river origin may be inferred depending on the catch location. Third, accurate sea-ages can be ascribed to individuals from scale readings and, fourth, annual re-sampling is more achievable. By collecting and analysing the tissues of returning adult salmon, it is possible to make inferences about the environmental changes at sea during their migration by using 'proxy' methods including stable isotope analysis (e.g. Gao \& Beamish 1999, Trueman \& Moore 2007, Dempson et al. 2009, Sinnatamby et al. 2009, MacKenzie et al. 2011). Examining chemical signals incorporated into biomineralised structures such as otoliths can provide insight into the details of thermal, metabolic and dietary histories of these elusive and long-distance migrants.

Otoliths are biomineralised aragonite structures of the inner ear of teleost fish (Popper \& Coombs 1982, Popper \& Lu 2000). Otolith growth is continuous, often displaying annual (macroscopic) and daily (microscopic) banding, and the structure is metabolically inert after formation. Unlike fish scales, otoliths are not susceptible to resorption (Campana \& Thorrold 2001) and so provide an environmental and physiological record of fish life history. Because of these features, otoliths can be sub-sampled at high resolution to provide ontogenetic patterns of stable isotope variation $\left(\delta^{13} \mathrm{C}\right.$ and $\left.\delta^{18} \mathrm{O}\right)$ over the relatively short time periods of days to weeks. Similar to inorganic aragonite, $\delta^{18} \mathrm{O}$ values of otolith aragonite are deposited at or near equilibrium with the ambient water composition (Campana 1999, Kim et al. 2007). Fractionation is mediated by temperature; thus, the water temperature during otolith deposition can be resolved provided that the $\delta^{18} \mathrm{O}$ values of ambient water are known or can be estimated (Degens et al. 1969, Kalish 1991a, Patterson et al. 1993, Thorrold et al. 1997, Høie et al. 2004b, Storm-Suke et al. 2007). However, the few experimental derivations of otolith thermometry equations (from otolith $\delta^{18} \mathrm{O}$ values) have shown that the equation parameters are not consistent across species (Patterson et al. 1993, Thorrold et al. 1997, Høie et al. 2004b, Storm-Suke et al. 2007). Even within a species for which a specific equation has been derived, precision and accuracy of 
temperature estimates from otolith $\delta^{18} \mathrm{O}$ values vary up to several degrees Celsius (Høie et al. 2004a). Nevertheless, relative-if not absolute-differences in thermal history during the marine phase, and environmental conditions experienced over the course of that migration, will be preserved in otoliths.

In contrast to oxygen, carbon isotope ratios in fish otoliths are not deposited in isotopic equilibrium with the surrounding water (Kalish 1991a,b). Isotopic disequilibria of carbon isotope ratios can, however, provide information on the dietary and metabolic history of fish if the $\delta^{13} \mathrm{C}$ value of the ambient dissolved inorganic carbon (DIC) can be constrained (Mulcahy et al. 1979, Gauldie 1996, Thorrold et al. 1997, Sherwood \& Rose 2003, Wurster \& Patterson 2003, Tohse \& Mugiya 2004, Solomon et al. 2006, Dufour et al. 2007). However, partitioning metabolic and dietary carbon sources to otolith carbonate is difficult for freeranging wild fish in the open ocean. Notwithstanding these limitations, comparing thermal and metabolic/ dietary histories between and within individual salmon returning with different condition factors may provide insights into the oceanic conditions they experienced and indications as to how salmon may respond to future environmental changes. But to address such questions, high-resolution, detailed profiles for individual fish are necessary to permit examination of variation at appropriately small temporal scales.

The sagittal otoliths of 1SW Atlantic salmon are small ( $\sim \mathrm{mm}$ in ventral length), and the marine zone is only $\sim 1 \mathrm{~mm}$ in extent. Many studies have used micromilling techniques to analyse microgram samples of otolith material, and have provided detailed isotopic profiles at high resolution (Wurster \& Patterson 2003, Zazzo et al. 2006, Dufour et al. 2007, 2008). The technique relies on digital mapping of visible otolith growth increments and automated milling of consecutive sampling paths, which generally traverse a large otolith area. In contrast, secondary ion mass spectrometry (SIMS) allows in situ analysis of nanograms of otolith material-with individual spot sizes of $\sim 15 \mu \mathrm{m}$ diameter and 2 to $3 \mu \mathrm{m}$ depth. The beam can be directed to specific and discrete points on a small area of the otolith and provides isotopic measurements with similar analytical precision to traditional techniques. These advantages have made it a useful approach to examine anadromy in salmonids using strontium and sulphur stable isotopes (Godbout et al. 2010, 2011, Johnson et al. 2012), and to reconstruct individual thermal and metabolic histories using carbon and oxygen stable isotope profiles (Weidel et al. 2007). However, it is important to note that sample sizes often are limited by the higher costs of SIMS analyses and that some new tools in otolith microchemistry (e.g. compound specific isotope analysis; McMahon et al. 2011) cannot be used in conjunction with SIMS. Here, we consider SIMS to be an appropriate technique to obtain in situ measurements of $\delta^{18} \mathrm{O}$ and $\delta^{13} \mathrm{C}$ within the small spatial (>1 mm) and temporal ( 15 mo) scales necessary to examine marine life histories of individual wild Atlantic salmon (Hanson et al. 2010).

The aims of this SIMS study were to explore marine life-history strategies in wild Atlantic salmon by examining the pattern and variation in thermal histories and otolith $\delta^{13} \mathrm{C}$ values during the marine phase, and evaluating $\delta^{18} \mathrm{O}$ and $\delta^{13} \mathrm{C}$ variability between and within individuals, specifically in relation to their pre-spawning growth condition. We specifically sought evidence that fish returning in low somatic condition might have migrated to warmer areas of the Norwegian Sea, with poorer feeding opportunities. We also explore factors affecting variation in otolith $\delta^{13} \mathrm{C}$ values, including metabolic and dietary effects.

\section{MATERIALS AND METHODS}

\section{Sample collection and preparation}

Salmon Salmo salar were sampled during the 2009 netting season (June to August) from the coastal mixed-stock fisheries (Shearer 1986) at Melvich $\left(58.57^{\circ} \mathrm{N}, 3.92^{\circ} \mathrm{W}\right)$ and Armadale $\left(58.10^{\circ} \mathrm{N}, 4.57^{\circ} \mathrm{W}\right)$, northern Scotland. Fork length (to $0.5 \mathrm{~cm}$, rounded down) and weight (to $0.01 \mathrm{~kg}$ ) of each fish were measured, and scale samples were collected for aging and growth analysis. Condition factor was calculated by means of the relative mass index, $W_{\mathrm{r}}$ (Blackwell et al. 2000):

$$
W_{\mathrm{r}}=W / W_{\mathrm{s}}
$$

where $W$ is the weight of the fish at capture and $W_{\mathrm{s}}$ is the standard weight predicted from a specific length/ weight regression equation for salmon sampled at the fishery. This was derived by the regression length percentile method, treating 14 yr-classes as separate populations and regressing the 75th percentile of $\log$ (weight) at each $1 \mathrm{~cm}$ grouping against log(length) (Todd et al. 2008). Scales were taken from the standard region for Atlantic salmon, 3 to 6 rows above the lateral line and posterior to the dorsal fin (Shearer 1992). The sea-age and river-age of each individual were determined by visual inspection of the pattern of deposition of the scale circuli (Bryce 
Whyte, Marine Scotland, Montrose). Both sagittal otoliths were removed, cleaned of any membrane, rinsed with deionised water and stored dry in sterile Eppendorf tubes. Otoliths were visually checked to eliminate those with vateritic formations, and a single vaterite-free otolith was taken from each of a subsample of 10 fish. Otoliths were set in epoxy resin mounts (Epo-Thin ${ }^{\circledR}$, Buehler), ground to the core (otolith origin) along the frontal plane using P1200, P2500 and P4000 grit SiC paper and polished flat with Alumina $0.3 \mu \mathrm{m}$ polishing suspension. Samples were coated with a $\sim 30 \mathrm{~nm}$ gold coat. On completion of the $\delta^{18} \mathrm{O}$ analyses, and prior to $\delta^{13} \mathrm{C}$ analyses, the blocks were lightly polished to remove SIMS ablation pits.

\section{SIMS analysis}

Reflected light photomicrographs of the sample mount guided the sampling procedure. Oxygen and carbon isotope ratios were measured with a Cameca IMS-1270 ion microprobe (No. 309) (University of Edinburgh) using a $\sim 5 \mathrm{nA}$ primary ${ }^{133} \mathrm{Cs}^{+}$beam focused to $15 \mu \mathrm{m}$ diameter. Step sizes between spots averaged $50 \mu \mathrm{m}$. For oxygen 2-isotope analyses, secondary ions were extracted at $-10 \mathrm{kV}$, and ${ }^{16} \mathrm{O}$ and ${ }^{18} \mathrm{O}$ were monitored simultaneously on dual Faraday cups (L'2 and H'2) at intensities of $3 \times 10^{9}$ and $4 \times 10^{6}$ counts per second (cps), respectively. Mass resolution was 2600 for oxygen to remove ${ }^{16} \mathrm{O}^{2} \mathrm{H}$ and ${ }^{17} \mathrm{O}^{1} \mathrm{H}$ on ${ }^{18} \mathrm{O}$. A single analysis took $4 \mathrm{~min}$, including a presputtering time of $40 \mathrm{~s}$, followed by automatic secondary beam and entrance slit centring and finally data collection in 2 blocks of 10 cycles (total $100 \mathrm{~s}: 5 \mathrm{~s}$ $\times 20$ cycles). For the carbon 2-isotope analyses, ${ }^{13} \mathrm{C}$ and ${ }^{12} \mathrm{C}$ were monitored simultaneously using an electron multiplier for ${ }^{13} \mathrm{C}$ and a Faraday cup (L'2) for ${ }^{12} \mathrm{C}$ at intensities of $3 \times 10^{5}$ and $3 \times 10^{7} \mathrm{cps}$, respectively. Mass resolution was $\sim 3000$ to remove ${ }^{12} \mathrm{C}^{1} \mathrm{H}$ on ${ }^{13} \mathrm{C}$. Each analysis took $6 \mathrm{~min}$, including a pre-sputtering time of $60 \mathrm{~s}$, followed by automatic secondary beam and entrance slit centring and finally data collection in 2 blocks of 20 cycles (total $200 \mathrm{~s}$ : $5 \mathrm{~s} \times 40$ cycles). A series of 10 to 15 unknown sample measurements were bracketed by 5 or 10 spot analyses of an internal reference material (University of Wisconsin-calcite) to assess instrumental fractionation, including the effect of electron multiplier ageing. Internal precision of a single measurement was $0.01 \% \mathrm{SE}$, and external reproducibility (i.e. spot-to-spot reproducibility of multiple measurements of the UWCcalcite reference material over the duration of analyses) was $<0.21 \%$ o SD for $\delta^{18} \mathrm{O}$ and $<0.43 \%$ o SD for $\delta^{13} \mathrm{C}$. Significant drift occurred over analytical sessions; corrections resulted in a reduction of the average standard deviation on 115 UWC-calcite pits over the $5 \mathrm{~d}$ of analysis from 0.23 to $0.06 \%$ for $\delta^{18} \mathrm{O}$ and from 1.33 to $0.34 \%$ for $\delta^{13} \mathrm{C}$. For all otolith isotope analyses, the $\delta^{18} \mathrm{O}$ and $\delta^{13} \mathrm{C}$ values are reported relative to Vienna Pee Dee Belemnite (VPDB) (Coplen 1996). Each sampling transect originated at the outer margin of the otolith and was terminated once a freshwater isotope signal was recorded (typically $\sim 1 \mathrm{~mm}$ from the otolith edge). A duplicate $\delta^{18} \mathrm{O}$ transect, offset by approximately $25 \mu \mathrm{m}$ from the original, was completed for Fish A3. All otolith analyses are reported in per mil (\%o) notation relative to VPDB.

\section{Statistical analysis}

Because sampling transects progressed inwards from the otolith margin to the core of the otolith, the point at which isotope profiles began to reflect freshwater rather than marine residency was recognizable as a substantial decrease in $\delta^{18} \mathrm{O}$ and $\delta^{13} \mathrm{C}$ values of $\sim 4 \%$ within $\sim 50$ to $100 \mu \mathrm{m}$ (Hanson et al. 2010). To compare isotope profiles between fish, it was necessary to demarcate a value for the start of the marine migration, to exclude those values reflecting the freshwater environment, and to re-scale the abscissa to a proportional distance from the freshwater/ marine transition. Consequently, all profiles were truncated near the transition (identified visually) to include $\delta^{18} \mathrm{O}$ values which were more than $-4 \%$ and $\delta^{13} \mathrm{C}$ values which were more than $-9 \%$. Distances were re-scaled as proportional distances along the otolith, with the first value of the 'marine zone' equal to zero and the final value at the outer margin of the otolith equal to one.

Because we were most interested in amongindividual variation due to condition factor differences, fish were separated into 2 groups according to $W_{\mathrm{r}}\left(\right.$ Group A, $W_{\mathrm{r}}>0.90$ and Group B, $\left.W_{\mathrm{r}}<0.90\right)$. We modelled the relationship between isotope values and their location across the otolith transect (representing a progression through time) using penalised regression spline generalised additive models (GAM; mgCV package; Wood 2011). This approach allows the analysis of regression models comprising both parametric or fixed effects (sex, $W_{\text {r group and river }}$ age) and nonparametric or nonlinear covariates (distance along the otolith transect). Isotope data were modelled as a smoothed function of proportional distance along the otolith and including the effects of sex, condition factor group, river age and individual. 
Individual fish-specific effects were included to account for variability between individuals and for the correlation in individual profiles which results from longitudinal measurements. In one model (2; see Table 2), we specifically included a smoothed function of isotope variation by distance along the otolith for each $W_{\text {r }}$ group to test for significant differences in the pattern of isotope variation between Groups A and B. A backwards stepwise approach was taken for model selection, and models were compared using a bias corrected Akaike information criterion (AICc) (Akaike 1976, Hurvich \& Tsai 1989). All GAMs used an identity link function and Gaussian distribution. Visual inspection of model residuals allowed the determination of outliers. All statistical analyses were performed in the statistical package $\mathrm{R}$ (R Core Development Team 2011).

\section{Chronology estimation}

To relate otolith transects to seasonal variation, it was necessary to estimate the deposition time for each otolith spot. We used scale growth circulus increments for this estimation because using the spacing of micro-increments in the otoliths themselves poses 2 problems. First, it was difficult to obtain an appropriate thin section for all otolith sections following SIMS analyses; second, the timing and validation of otolith increment formation in adult Atlantic salmon is not well understood. Although otoliths are acellular, their precipitation is linked to somatic growth (and hence also to scale growth increments) because of the importance of organic molecules in providing nucleation sites (Degens et al. 1969, Campana \& Thorrold 2001, Murayama et al. 2002, Wells et al. 2003). Whilst increment formation has been characterised for embryonic and juvenile salmon (Geffen 1983, Wright et al. 1991), only one study has attempted to estimate the timing of otolith formation in adult Atlantic salmon. For pen-reared captive salmon, Wells et al. (2003) estimated average micro-increment deposition time to be just over $1 \mathrm{wk}$ (8 d) in 1SW salmon; they also noted correlations between scale circuli widths and otolith increment widths in wild adult salmon that were presumed to be related to seasonal growth patterns. In the absence of reliable growth increment analyses of the otoliths themselves, we therefore used scale circulus increment analyses as a nonlinear proxy to estimate the deposition time of each SIMS spot. Back-calculation of body length by means of the Dahl-Lea method, which assumes linearity between scale radius and fish length, is typically applied in growth studies of Atlantic salmon (e.g. Heidarsson et al. 2006, Jensen et al. 2011). However, circulus deposition clearly is nonlinear over time. As an illustration of the temporal nonlinearity of scale circulus deposition of 1SW salmon scales, the mean days between circuli for the pre-winter and post-winter growth periods of 23 tagged 1SW fish of known emigration and capture date were, respectively, 8.1 and $11.0 \mathrm{~d}$ (C. D. Todd unpubl. data). This nonlinearity arises from the interaction between the direct relationship between body length and otolith/scale size, and the declining temporal rate of circulus deposition as fish body length increases (i.e. an increment measurement during a period of rapid fish growth will represent less time than a similar increment measurement during a period of slower growth). Here, we allowed for the progressive increase in temporal spacing of circuli by fitting a simple quadratic model to circulus increment over the time at sea.

Measurements of scale circulus spacings were made from acetate impressions of individual scales using a Wild M8 microscope connected to an image analysis system (analySIS 2.0; Soft-Imaging Software). The marine winter growth check annulus is easily recognisable on scales of 1SW salmon and typically comprises 2 to 12 circuli (C. D. Todd unpubl. data). Measurements were made at a resolution of $\sim 4$ to $7 \mu \mathrm{m}$ from the scale focus to (1) the transition at smolt emigration to sea, (2) the middle of the marine winter growth check annulus (i.e. marked contraction of spacing of scale circuli associated with decreased growth during winter), and (3) the scale edge along the longest scale axis (Fig. 1).

For the purpose of establishing a chronology, the timings for these events were assumed to be 7 May (median date of $50 \%$ smolt emigration between 2006 and 2010 on the River North Esk, Scotland; J. C. MacLean, Marine Scotland, pers. comm.) and 21 December (the winter solstice). The winter solstice was used as the mid-winter date because salmon are visual predators (Wankowski 1977, Haugland et al. 2006) and can range northwards into high latitudes. At such latitudes, it is intuitive that the lack of available light during mid-winter would be the main constraint on prey capture and hence somatic growth. Evidence from research trawls and long-line fisheries indicates that Atlantic salmon are distributed to the north of the Faroes $\left(\sim 62^{\circ} \mathrm{N}\right)$ and move further northward and into the Norwegian Sea during winter (Jakupsstovu et al. 1988, Hansen \& Jacobsen 2000, Dadswell et al. 2010). Few hours of daylight are therefore available for foraging during the period 

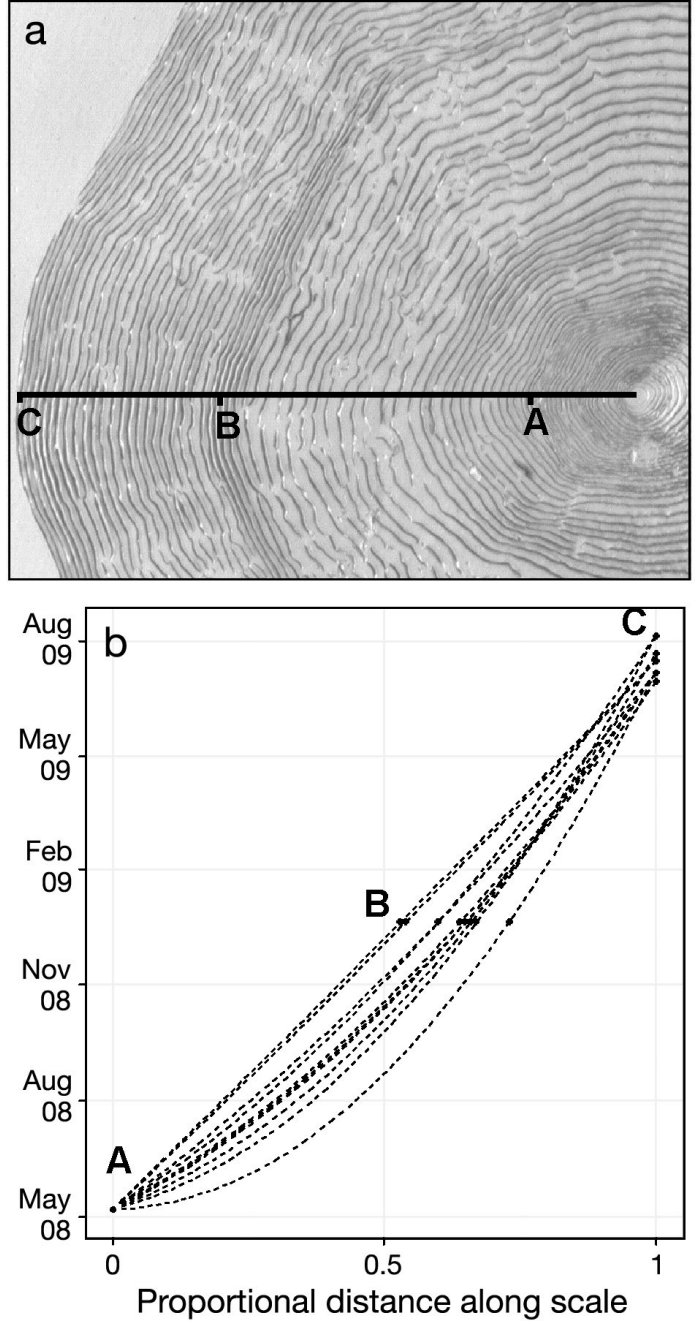

Fig. 1. Salmo salar. Scale growth increment analysis was used to estimate the timing of otolith secondary ion mass spectrometry (SIMS) spots. (a) 3 measurements were taken from salmon scales: A, smolt emigration to sea; B, the middle of the marine winter growth check annulus (i.e. marked contraction of spacing of scale circuli associated with decreased growth during winter); and $\mathrm{C}$, the scale edge. (b) These measurements were re-scaled to a proportional distance from smolt emigration and regressed against 3 fixed dates for these events. Smolt emigration was set to 7 May for all fish, the winter check was set to 21 December for all fish, and fish-specific catch dates were used as the final date for the scale edge. Quadratic functions $\left(r^{2}=1\right)$ were fitted for each individual fish and used to calculate dates for each SIMS otolith spot (also re-scaled as proportional distance from smolt emigration to otolith edge)

November to January. The date of capture provides the timing for the scale edge.

To relate scale circulus measurements to otolith SIMS spots, the former were re-scaled to proportional distance from the smolt emigration. The relationship between this proportional distance and fixed dates was then plotted for each individual fish. A quadratic equation of the form $a x^{2}+b x+c$ best described the relationship ( $\mathrm{r}^{2}=1$ in all model fits) between proportional distance and calendar date, likely because the timing of scale circulus formation is not ontogenetically constant, and growth in length decreases with size (Fig. 1). All otolith profiles were truncated at smolt emigration and re-scaled as a proportional distance so that the constants from the equations described above could be used to calculate an approximate calendar date at each SIMS spot. By using scale growth increments to estimate deposition time for specific spots on the otolith, we make several simplifying assumptions. First, we assume that both otolith and scale growth increments are nonlinear over time at sea. Second, we assume that scale growth is closely correlated to otolith growth for all individuals. Lastly, by assuming fixed dates for smolt emigration and the winter annulus check, we could not account for the relatively small but inevitable error associated with natural variation in the timing of these events.

\section{Otolith thermometry}

The isotopic partitioning of oxygen between otolith aragonite and ambient water can be described in terms of the isotopic fractionation factor, $\alpha$ :

$$
\alpha=\frac{\delta^{18} \mathrm{O}_{\text {otolith }}+1000}{\delta^{18} \mathrm{O}_{\text {seawater }}+1000}
$$

Temperature-dependent fractionation is described as:

$$
1000 \ln \alpha=a+b\left(10^{3} \mathrm{TK}^{-1}\right)
$$

where $a$ is the estimated regression intercept, $b$ the estimated slope coefficient and TK is water temperature in degrees Kelvin (K). The parameters $a$ and $b$ have not yet been measured empirically for wild Atlantic salmon; to date, the most closely related species for which there is an otolith thermometry equation is Arctic charr Salvelinus alpinus (Storm-Suke et al. 2007), whereby $a=-41.69$ and $b=20.69$.

Whilst relative differences in thermal profiles rather than absolute temperature estimates were the primary focus of the present study, an attempt was made to provide a more appropriate equation specifically for Atlantic salmon by estimating a from the present data and assuming a slope of $b=17.88 \pm 0.13$ derived for the fractionation between water and synthetic aragonite (Kim et al. 2007). The second unknown parameter, $a$, was calculated by solving Eq. (3): $\delta^{18} \mathrm{O}_{\text {otolith }}$ was calculated by averaging the final otolith $\delta^{18} \mathrm{O}$ transect values (i.e. the most recent 
growth prior to capture) for fish caught in the month of July, 2009 ( $\mathrm{n}=5$ individuals; mean $\pm \mathrm{SD}=1.15 \pm$ $0.3 \%$ ). The sea-surface $(0$ to $10 \mathrm{~m}) \delta^{18} \mathrm{O}_{\text {seawater value }}$ was extracted from a global database (LeGrande \& Schmidt 2006) for the gridbox centred north of the coastal fisheries $\left(59.5^{\circ} \mathrm{N}, 3.5^{\circ} \mathrm{W}\right)$ - the more northerly gridbox was used because no data were available for the gridbox centred at $58.5^{\circ} \mathrm{N}, 3.5^{\circ} \mathrm{W}$. Using the July 2009 mean sea surface temperature (SST) estimate from the oiSSTv2 (Reynolds et al. 2002) dataset for same gridbox $\left(13.91^{\circ} \mathrm{C}\right) 10^{3} \mathrm{TK}^{-1}$ was calculated. The intercept (a) was estimated to be $-33.43 \pm 0.37$. Temperature estimates for the whole otolith profile were then calculated from this derived equation for comparison with that of Storm-Suke et al. (2007).

For calculating temperatures from all measured otolith $\delta^{18} \mathrm{O}$, we assumed $\delta^{18} \mathrm{O}_{\text {seawater }}=0.276 \pm 0.16 \%$ o (mean $\pm \mathrm{SD})$; this is the value from LeGrande \& Schmidt (2006) for the uppermost $10 \mathrm{~m}$ of a large region of the eastern North Atlantic encompassing the presumed Atlantic salmon migratory range (57 to $70^{\circ} \mathrm{N}, 20^{\circ} \mathrm{W}$ to $20^{\circ} \mathrm{E}$ ) (Hansen \& Jacobsen 2000). Vienna standard mean ocean water (VSMOW) values were converted to the VPDB scale using the equation by Coplen et al. (1983):

$$
\delta^{18} O_{V S M O W}=1.03091 \delta^{18} O_{V P D B}+30.91
$$

The analytical error associated with a single otolith isotope measurement, $0.21 \%$, corresponds to $<1^{\circ} \mathrm{C}$.

\section{Estimation of the metabolic component of $\delta^{13} \mathrm{C}$}

$\delta^{13} \mathrm{C}$ variation in aragonitic otoliths arises from the mixing of bicarbonate of the DIC component of ambient water and metabolically derived bicarbonate in the blood (which is itself reflective of dietary carbon); this can be described by a mass-balance model (Schwarcz et al. 1998, Wurster \& Patterson 2003, Dufour et al. 2007) such that:

$$
\begin{aligned}
& \delta^{13} \mathrm{C}_{\text {otolith }}=M\left(\delta^{13} \mathrm{C}_{\text {diet }}+\varepsilon_{\text {blood-diet }}\right) \\
& +(1-M)\left(\delta^{13} \mathrm{C}_{\text {DIC }}+\varepsilon_{\text {blood-water }}\right) \\
& +\varepsilon_{\text {endolymph-blood }}+\varepsilon_{\text {otolith-endolymph }}
\end{aligned}
$$

where $M$ describes the proportion of metabolic carbon in the otolith and $\varepsilon_{\mathrm{A}-\mathrm{B}}$ is an isotopic enrichment factor describing the fractionation of isotopes between the different carbon pools. Although these factors will depend also on the value of $M$, for present purposes they were simplified to a single metric, $\varepsilon_{\text {total }}$, describing the total fractionation between all carbon sources and the otolith. This has been estimated to be between $2.7 \%$ o $( \pm 0.6)$ for inorganic aragonite (Romanek et al. 1992) and $-1.8 \%$ o $( \pm 1.8)$ for biogenic aragonite (estimated from the full model in Solomon et al. 2006). To estimate the possible range in $M$ from salmon otolith $\delta^{13} \mathrm{C}$ values, we varied the known variables over plausible values $\left(\delta^{13} \mathrm{C}_{\text {DIC }}=0\right.$ to $2.2 \%$; $\delta^{13} C_{\text {diet }}=-23$ to $-17.4 \%$; $\varepsilon_{\text {total }}=0$ to $2.7 \%$; Gruber et al. 1999, Sato et al. 2002, Møller 2006, Søreide et al. 2006) and solved Eq. (5) for $M$ ).

\section{RESULTS}

Two otoliths, B3 and B5, of Salmo salar were excluded from $\delta^{18} \mathrm{O}$ analyses due to instrument time constraints, and 1 otolith, B4, was excluded from $\delta^{13} \mathrm{C}$ analyses because it was inadvertently destroyed during SIMS analysis. For the duplicate $\delta^{18} \mathrm{O}$ transect, scanning electron microscope images guided the matching of points to particular growth zones, and the matched profiles were found to be highly correlated (Fig. 2; Pearson's $\mathrm{r}^{2}=0.89, \mathrm{p}<0.001$ ), affirming that
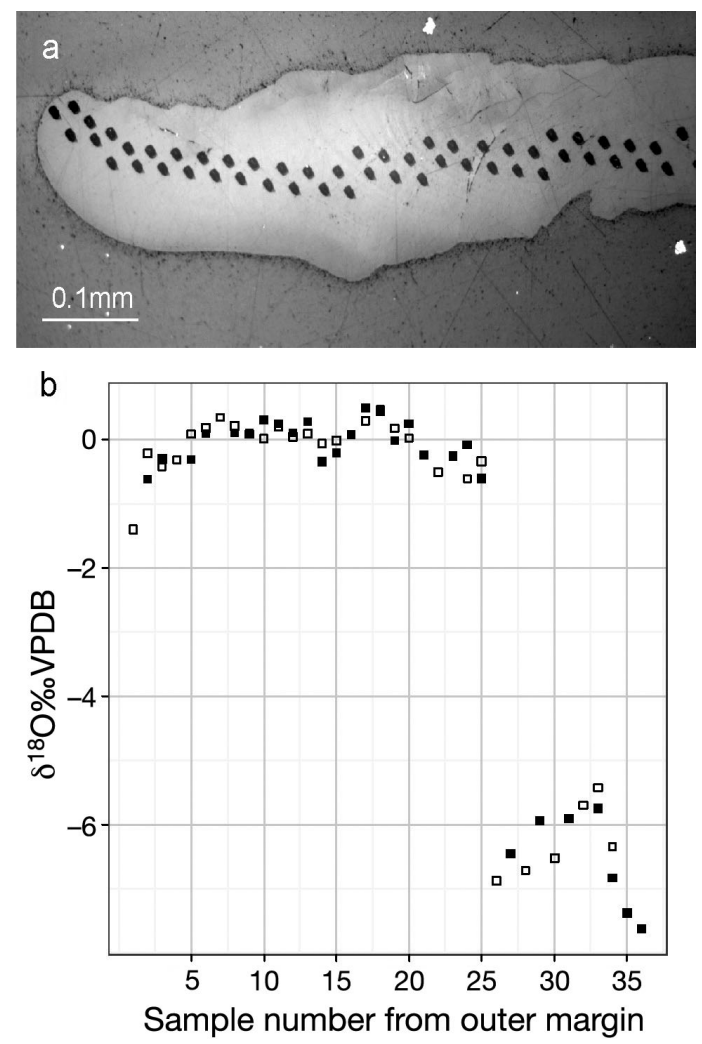

Fig. 2. Salmo salar. Duplicate transects of SIMS spots on (a) Otolith A3 and (b) $\delta^{18} \mathrm{O}( \pm 0.21 \%$ ) values (in Vienna Pee Dee Belemnite, VPDB) after scanning electron microscope images guided the matching of replicate points to growth layers. Open squares: original transect; closed squares: duplicate transect offset by approximately $25 \mu \mathrm{m}$ from the original 
the pattern of stable isotope variation is repeatable across the transverse section irrespective of the precise alignment of the transect. SIMS sample pits were $\sim 15 \mu \mathrm{m}$ in diameter. For each otolith, 24 to 34 analyses were obtained for $\delta^{18} \mathrm{O}$ (a total of 314 measurements from 8 individuals; Fig. 3) and 11 to 24 analyses per otolith for $\delta^{13} \mathrm{C}$ (a total of 157 measurements from 9 individuals; Fig. 4). $\delta^{18} \mathrm{O}$ values in the marine zone ranged from -3.57 to $1.11 \%$ and $\delta^{13} \mathrm{C}$ from -11.08 to $-2.77 \%$ o (Table 1 ; Fig. 5).

The best-fit model for both $\delta^{18} \mathrm{O}$ and $\delta^{13} \mathrm{C}$ was Model 1 (Table 2), which included all 3 fixed effects ( $W_{\mathrm{r}}$ group, sex and river) and proportional distance along the otolith transect as a highly significant nonlinear predictor. All fixed effects, except the $\delta^{13} \mathrm{C}$ intercept, were not significantly different from zero (Table 3). The effect of lower condition factor (Group
B) on the intercept was negative for both $\delta^{18} \mathrm{O}$ and $\delta^{13} \mathrm{C}$ values, although the standard error associated with these estimates was high and the result was not significant. Whilst a 'low' condition factor group was defined here as $W_{\mathrm{r}}<0.90, W_{\mathrm{r}}=0.97$ is, in fact, 'normal' or 'average' because of the use of 75th percentiles in generating the predictive equation (Todd et al. 2012). Therefore, the majority of the fish sampled here may be considered 'skinny'. An increased number of individuals in 'good' to 'normal' condition would be necessary to more robustly determine the differences in marine environmental conditions experienced by each group.

From variance components it is apparent that intraotolith variation dominated (Table 3): $~ 90 \%$ of variability in otolith $\delta^{18} \mathrm{O}$ and $\delta^{13} \mathrm{C}$ values could be attributed to distance along the transect (i.e. time), while
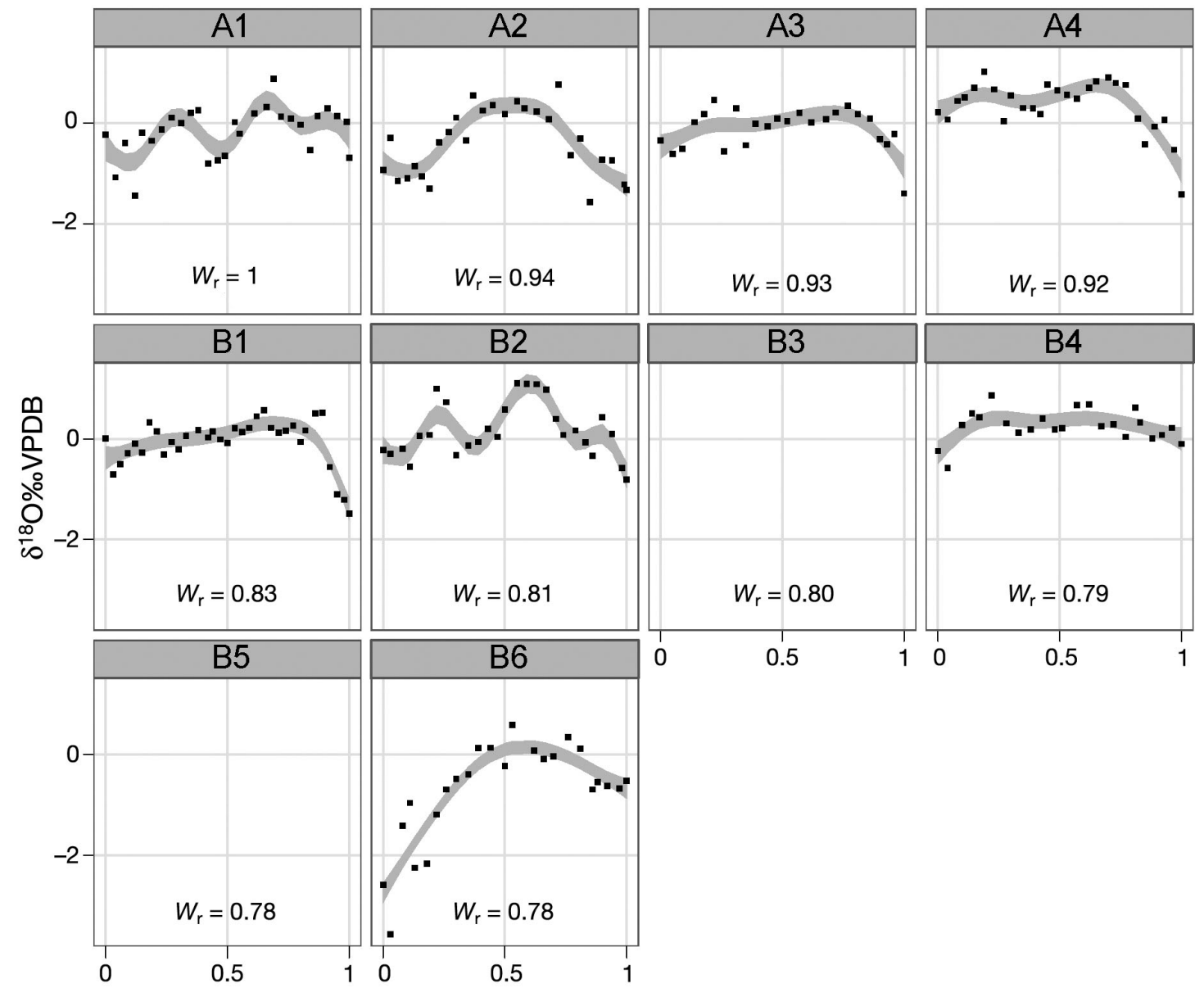

Proportional distance along otolith marine zone

Fig. 3. Salmo salar. Penalised regression spline smooths of individual $\delta^{18} \mathrm{O}$ profiles within the marine zone scaled to a proportional distance from the freshwater-marine transition $(0=$ smolt emigration, $1=$ capture as adults in coastal waters $)$. Generalised additive model smoothes and $95 \%$ confidence intervals were generated for each individual. The condition factor $\left(W_{\mathrm{r}}\right)$ for each fish is given on individual plots, with distinctions between relatively high (A) and low (B) condition groupings. Two otoliths, B3 and B5, were excluded from $\delta^{18} \mathrm{O}$ analyses due to instrument time constraints. VPDB: Vienna Pee Dee Belemnite 
among-fish variance was much lower. Fitted GAM output functions of $\delta^{18} \mathrm{O}$ and $\delta^{13} \mathrm{C}$ values by proportional otolith distance are presented in Fig. 5. $\delta^{18} \mathrm{O}$ values increased $\sim 1 \%$ o from $-0.7 \%$ o to a maximum of $0.4 \%$ just over halfway between smolt emigration and the otolith edge. $\delta^{13} \mathrm{C}$ values increased from $-7.4 \%$ o to a maximum of $-4.8 \%$ at $\sim 0.8 \%$ along the proportional marine zone otolith distance. For 6 out of 9 individuals, $\delta^{13} \mathrm{C}$ values declined precipitously over the last $\sim 20 \%$ of the otolith transect (Fig. 4 ), but this pattern was not related to condition factor group.

The approximated chronology from fish scales was used to plot estimated thermal histories for all fish (Fig. 6a). The general seasonal pattern of water temperatures estimated from otolith $\delta^{18} \mathrm{O}$ was curvilinear. Salmon moved gradually from warm, coastal waters after smolt emigration to the coldest waters within the winter months (November to February).
Water temperatures increased again during the final months prior to capture in coastal waters. The range of temperatures predicted using the Storm-Suke et al. (2007) equation was from 10.41 to $29.86^{\circ} \mathrm{C}$ (mean $\pm \mathrm{SD}=15.66 \pm 2.61^{\circ} \mathrm{C}$ ), whereas the range predicted from the derived equation was 3.19 to $24.77^{\circ} \mathrm{C}$ $\left(8.41 \pm 2.97^{\circ} \mathrm{C}\right)$. Including the potential variance in $\delta^{18} \mathrm{O}_{\text {seawater, }} a$ and $b$ (from Eq. 3) in temperature calculations resulted in an increase of the standard deviation of the mean from approximately \pm 3 to $\pm 6^{\circ} \mathrm{C}$.

Allowing the input variables to range over plausible values of $\delta^{13} \mathrm{C}_{\text {DIC }} \delta^{13} \mathrm{C}_{\text {diet }}$ and $\varepsilon_{\text {total, }}$ the metabolic contribution of carbon $(\% M)$ to otolith aragonite in the present study varied widely from 4 to $81 \%$. Over the marine life of salmon, these values typically fluctuated by $\sim 33$ to $48 \%$ and followed a clear ontogenetic pattern (Fig. 6b) of decline until the last few months at sea, when estimated \%M increased markedly.

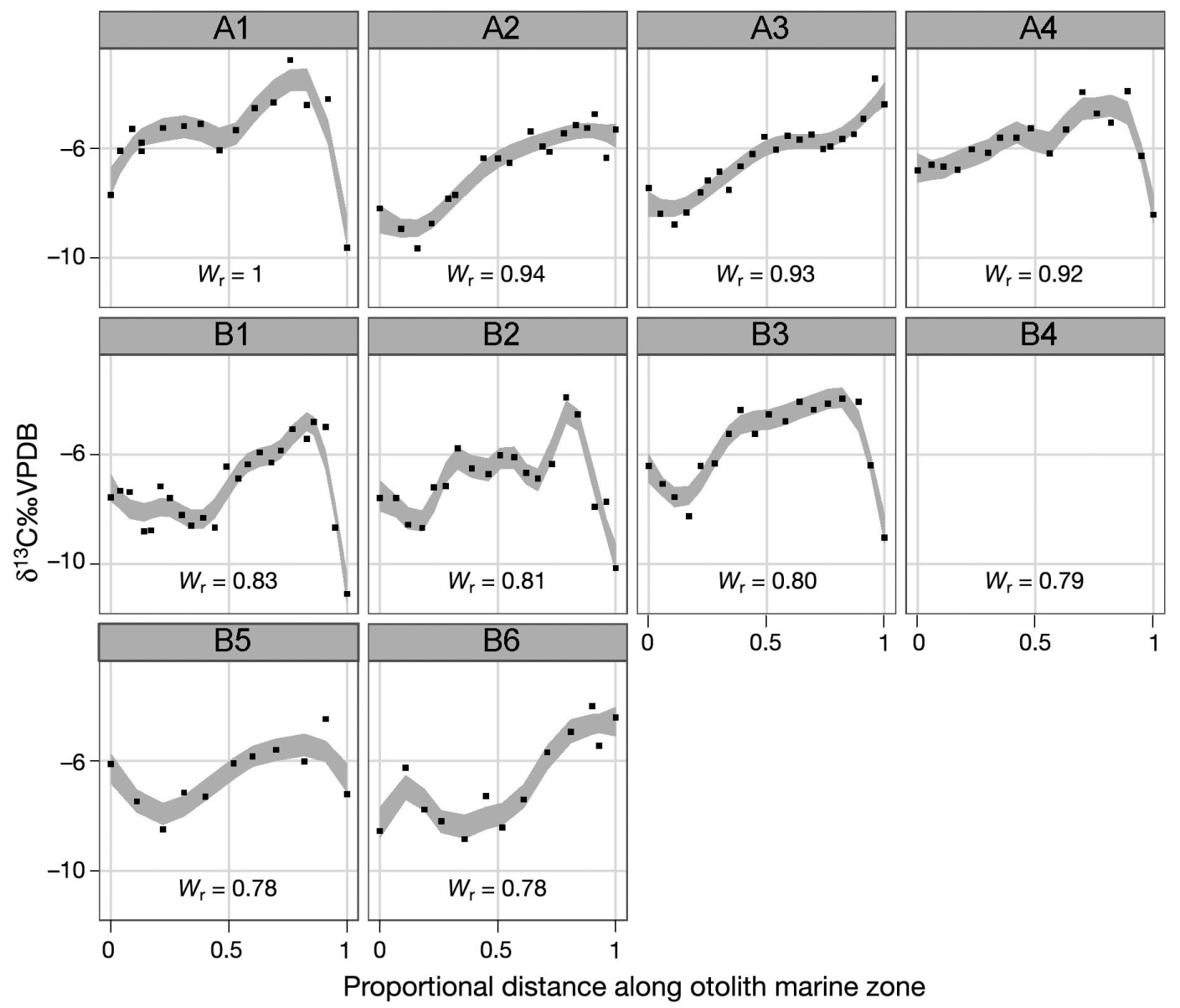

Fig. 4. Salmo salar. Penalised regression spline smooths of individual $\delta^{13} \mathrm{C}$ profiles within the marine zone scaled to a proportional distance from the freshwater-marine transition $(0=$ smolt emigration, $1=$ capture as adults in coastal waters $)$. Generalised additive model smoothes and $95 \%$ confidence intervals were generated for each individual. The condition factor $\left(W_{\mathrm{r}}\right)$ for each fish is given on individual plots, with distinctions between relatively high (A) and low (B) condition groupings. One otolith, B4, was excluded from $\delta^{13} \mathrm{C}$ analyses because it was inadvertently destroyed during SIMS analysis. VPDB: Vienna Pee 
Table 1. Salmo salar. Summary of the $\delta^{18} \mathrm{O}$ and $\delta^{13} \mathrm{C}$ values obtained within the marine zone of otoliths from 1 sea-winter Atlantic salmon by secondary ion mass spectrometry analyses. All isotope ratios are reported relative to Vienna Pee Dee Belemnite. $W_{\mathrm{r}}$ : condition factor; ND: no data

\begin{tabular}{|c|c|c|c|c|c|c|c|c|c|c|c|c|c|}
\hline \multirow[t]{2}{*}{ ID } & \multirow{2}{*}{ Catch date } & \multirow[t]{2}{*}{ Sex } & \multirow{2}{*}{$\begin{array}{l}\text { Length } \\
\text { (cm) }\end{array}$} & \multirow{2}{*}{$\begin{array}{c}\text { Weight } \\
(\mathrm{kg})\end{array}$} & \multirow{2}{*}{$W_{\mathrm{r}}$} & \multicolumn{4}{|c|}{$\delta^{18} \mathrm{O}(\%)$} & \multicolumn{4}{|c|}{$\delta^{13} \mathrm{C}(\% \circ)$} \\
\hline & & & & & & $\mathrm{n}$ & Max. & Min. & $\sigma$ & $\mathrm{n}$ & Max. & Min. & $\sigma$ \\
\hline A1 & 7 Jul 2009 & M & 58.8 & 2.44 & 1 & 28 & 0.88 & -1.44 & 0.49 & 16 & -2.77 & -9.62 & 1.65 \\
\hline A2 & 7 Jul 2009 & $\mathrm{~F}$ & 57.5 & 2.15 & 0.94 & 27 & 0.77 & -1.57 & 0.67 & 18 & -4.74 & -9.65 & 1.48 \\
\hline A3 & 30 Jun 2009 & $\mathrm{~F}$ & 54 & 1.76 & 0.93 & 24 & 0.46 & -1.4 & 0.41 & 22 & -3.45 & -8.77 & 1.34 \\
\hline A4 & 16 Jul 2009 & M & 57.5 & 2.1 & 0.92 & 27 & 1.02 & -1.42 & 0.53 & 17 & -3.9 & -8.42 & 1.12 \\
\hline B1 & 7 Jul 2009 & M & 56 & 1.74 & 0.83 & 34 & 0.57 & -1.49 & 0.48 & 23 & -4.79 & -11.08 & 1.54 \\
\hline B2 & 5 Aug 2009 & M & 49.4 & 1.16 & 0.81 & 27 & 1.11 & -0.81 & 0.55 & 19 & -3.91 & -10.14 & 1.43 \\
\hline $\mathrm{B}^{\mathrm{a}}$ & 7 Jul 2009 & $\mathrm{~F}$ & 55.2 & 1.62 & 0.8 & ND & ND & ND & ND & 18 & -3.94 & -9.03 & 1.57 \\
\hline $\mathrm{B} 4^{\mathrm{b}}$ & 5 Aug 2009 & M & 56.3 & 1.7 & 0.79 & 23 & 0.87 & -0.58 & 0.31 & ND & ND & ND & ND \\
\hline $\mathrm{B} 5^{\mathrm{a}}$ & 16 Jul 2009 & $\mathrm{~F}$ & 53.6 & 1.44 & 0.78 & ND & ND & ND & ND & 11 & -4.46 & -8.5 & 1.12 \\
\hline B6 & 22 Jul 2009 & M & 62.4 & 2.29 & 0.78 & 24 & 0.59 & -3.57 & 1.02 & 13 & -3.99 & -8.85 & 1.68 \\
\hline All & & & & & & 214 & 1.11 & -3.57 & 0.66 & 157 & -2.77 & -11.08 & 3 \\
\hline
\end{tabular}

${ }^{\mathrm{a}} \delta^{18} \mathrm{O}$ results were not obtained for 2 otoliths due to time constraints and an instrumental error; ${ }^{\text {b }} \delta^{13} \mathrm{C}$ data were not obtained for Fish B4 because this otolith was accidentally destroyed during sampling

\section{DISCUSSION}

The aim of the present study was to explore highresolution $\delta^{18} \mathrm{O}$ and $\delta^{13} \mathrm{C}$ variation within and between the marine zone of otoliths of 1SW Atlantic salmon Salmo salar, especially in relation to somatic condition of the returning adult fish. We use otolith $\delta^{18} \mathrm{O}$ values as a proxy for water temperature, but discuss below the uncertainties associated with predicting absolute water temperatures using otolith thermometry in a wild, free-ranging marine fish. Possible factors governing $\delta^{13} \mathrm{C}$ variation are discussed and among-individual differences highlighted.

\section{Thermal histories}

Because temperature-dependent oxygen isotope fractionation between aragonite and water exists (Kim et al. 2007), otolith $\delta^{18} \mathrm{O}$ marine values should be driven primarily by 2 variables: the $\delta^{18} \mathrm{O}$ value of the ambient water $\left(\delta^{18} \mathrm{O}_{\text {seawater }}\right)$ and water temperature. Ultimately, the $\delta^{18} \mathrm{O}$ values of oceanic waters are reflective of their source; $\delta^{18} \mathrm{O}$ values have been empirically measured for many water masses (Schmidt et al. 1999, Frew et al. 2000) and globally interpolated by LeGrande \& Schmidt (2006). Both freshwater inputs and the presence of sea ice can have large effects on oceanic $\delta^{18} \mathrm{O}$ values. Therefore, variation in salmon $\delta^{18} \mathrm{O}_{\text {otolith }}$ profiles could be attributable to their migration between areas characterised by different ambient water $\delta^{18} \mathrm{O}$ signatures, movement between areas of differing temperatures and/or seasonal changes in ambient water $\delta^{18} \mathrm{O}$ signatures. To estimate thermal histories, it was necessary to set a con-
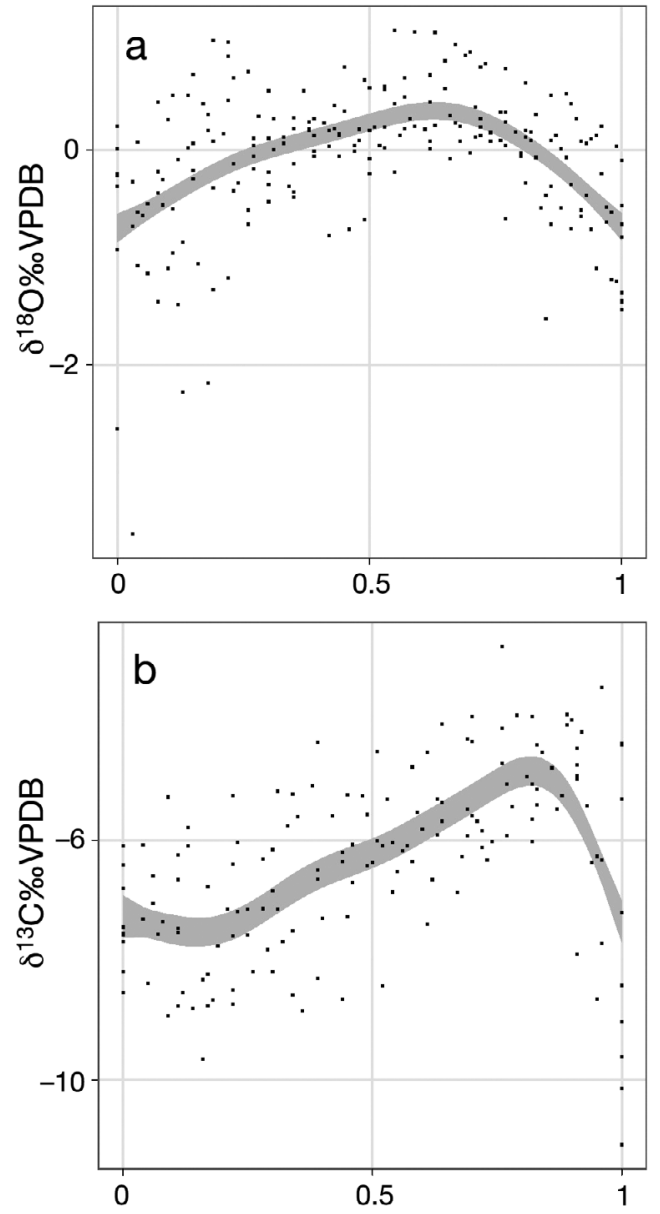

Fig. 5. Salmo salar. Fitted Generalised additive model smooths and $95 \%$ confidence intervals of (a) otolith $\delta^{18} \mathrm{O}$ values and (b) $\delta^{13} \mathrm{C}$ values as a function of the proportional distance on the otolith from the position of smolt emigration. A single otolith from each of 8 and 9 individual salmon, respectively, was analysed for $\delta^{18} \mathrm{O}(\mathrm{n}=214$ SIMS spots $)$ and $\delta^{13} \mathrm{C}(\mathrm{n}=157$ SIMS spots). VPDB: Vienna Pee Dee Belemnite 
Table 2. Salmo salar. Summary of the generalised additive models fit to $\delta^{18} \mathrm{O}$ and $\delta^{13} \mathrm{C}$ values obtained within the marine zone of otoliths from 1 sea-winter Atlantic salmon by secondary ion mass spectrometry analyses. Models were selected by backwards stepwise selection and corrected Akaike information criterion (AICc) reduction (Hurvich \& Tsai 1989). $W_{\mathrm{r}}$ : condition factor; EDF: equivalent degrees of freedom; REML: restricted maximum likelihood

\begin{tabular}{|c|c|c|c|c|c|c|c|c|c|c|}
\hline \multirow[t]{2}{*}{ Model } & \multicolumn{2}{|c|}{ Nonlinear effects } & \multirow[b]{2}{*}{ Sex } & \multirow{2}{*}{$\begin{array}{l}\text { Fixed effects } \\
W_{\mathrm{r}} \text { group }\end{array}$} & \multirow[b]{2}{*}{$\begin{array}{l}\text { River } \\
\text { age }\end{array}$} & \multirow{2}{*}{$\begin{array}{l}\text { Random effect } \\
\text { Individual }\end{array}$} & \multirow[t]{2}{*}{ EDF } & \multirow{2}{*}{$\begin{array}{l}\text { REML } \\
\text { score }\end{array}$} & \multirow[t]{2}{*}{$\mathrm{r}^{2}$} & \multirow[t]{2}{*}{$\mathrm{AICc}$} \\
\hline & $\begin{array}{l}\text { Otolith } \\
\text { distance }\end{array}$ & $\begin{array}{l}\text { Otolith } \\
\text { distance by } \\
W_{\mathrm{r}} \text { group }\end{array}$ & & & & & & & & \\
\hline \multicolumn{11}{|l|}{$\delta^{18} \mathrm{O}$} \\
\hline 1 & Yes & No & Yes & Yes & Yes & Yes & 19.96 & 143.13 & 0.61 & 250.98 \\
\hline 2 & No & Yes & Yes & Yes & Yes & Yes & 23.08 & 147.3 & 0.61 & 256.26 \\
\hline 3 & Yes & No & Yes & Yes & No & Yes & 19.93 & 144.13 & 0.61 & 251.09 \\
\hline 4 & Yes & No & No & Yes & No & Yes & 19.85 & 144.95 & 0.61 & 251.1 \\
\hline 5 & Yes & No & Yes & No & No & Yes & 19.84 & 144.77 & 0.61 & 251.16 \\
\hline 6 & Yes & No & No & No & No & Yes & 19.75 & 145.11 & 0.61 & 251.19 \\
\hline 7 & No & No & No & No & No & Yes & 14.37 & 195.02 & 0.31 & 368.35 \\
\hline \multicolumn{11}{|l|}{$\delta^{13} \mathrm{C}$} \\
\hline 1 & Yes & No & Yes & Yes & Yes & Yes & 21.15 & 242.52 & 0.59 & 464.78 \\
\hline 2 & No & Yes & Yes & Yes & Yes & Yes & 24.55 & 244.58 & 0.59 & 467.8 \\
\hline 3 & Yes & No & Yes & Yes & No & Yes & 20.79 & 243.27 & 0.58 & 464.95 \\
\hline 4 & Yes & No & No & Yes & No & Yes & 20.34 & 244 & 0.58 & 465.45 \\
\hline 5 & Yes & No & Yes & No & No & Yes & 20.52 & 243.91 & 0.58 & 464.86 \\
\hline 6 & Yes & No & No & No & No & Yes & 20.03 & 244.57 & 0.58 & 465.37 \\
\hline 7 & No & No & No & No & No & Yes & 15.41 & 274.99 & 0.34 & 532.36 \\
\hline
\end{tabular}

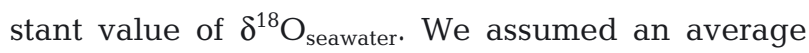
value for the top $10 \mathrm{~m}$ of a large region of the eastern North Atlantic, but the potential range of $\delta^{18} \mathrm{O}_{\text {seawater }}$ values in this region calculated from LeGrande \& Schmidt (2006) is $\sim 0.8 \%$ o $(-0.41$ to $0.47 \%$ o), which equates to a predicted temperature range of $\sim 3.5^{\circ} \mathrm{C}$ if $\delta^{18} \mathrm{O}_{\text {otolith }}$ is held constant. In reality, $\delta^{18} \mathrm{O}_{\text {otolith values }}$ vary over the course of a wild free-ranging Atlantic salmon's lifetime along with $\delta^{18} \mathrm{O}_{\text {seawater, making it }}$ impossible to accurately predict absolute water temperatures from otolith $\delta^{18} \mathrm{O}$. Nevertheless, relative differences in the thermal histories both between and within individuals are tractable, and we present water temperature estimates from both a field-

Table 3. Salmo salar. Summary of parameter estimates for semi-parametric Generalised Additive Model 1 fitted to Atlantic salmon otolith $\delta^{18} \mathrm{O}$ and $\delta^{13} \mathrm{C}$ profiles (see Table 2). NA: not available. Upper, lower: $95 \%$ confidence intervals

\begin{tabular}{|c|c|c|c|c|c|c|c|}
\hline Effect & Estimate & SE & $t$ & $\mathrm{SD}$ & Upper & Lower & $\mathrm{p}$ \\
\hline \multicolumn{8}{|l|}{$\delta^{18} \mathrm{O}$} \\
\hline Intercept & 0.093 & 0.561 & 0.165 & - & - & - & 0.869 \\
\hline Condition group (B) & -0.038 & 0.614 & -0.619 & - & - & - & 0.537 \\
\hline Sex (male) & 0.356 & 0.708 & 0.503 & - & - & - & 0.616 \\
\hline River age (3 yr) & -0.63 & 0.501 & -1.257 & - & - & - & 0.21 \\
\hline Distance & - & - & - & 6.53 & 2.87 & 14.86 & $<0.001$ \\
\hline Individual (intercept) & - & - & - & 0.694 & 0.335 & 1.436 & NA \\
\hline Individual (smooth) & - & - & - & 0.755 & 0.411 & 1.385 & NA \\
\hline Residual & - & - & - & 0.411 & 0.372 & 0.454 & NA \\
\hline \multicolumn{8}{|l|}{$\delta^{13} \mathrm{C}$} \\
\hline Intercept & -6.37 & 0.735 & -8.661 & - & - & - & $<0.001$ \\
\hline Condition group (B) & -0.383 & 0.763 & -0.502 & - & - & - & 0.617 \\
\hline Sex (male) & 0.573 & 0.807 & 0.71 & - & - & - & 0.479 \\
\hline River age (3 yr) & -0.288 & 0.809 & -0.356 & - & - & - & 0.722 \\
\hline Distance & - & - & - & 30.803 & 15.578 & 60.905 & $<0.001$ \\
\hline Individual (intercept) & - & - & - & 1.05 & 0.503 & 2.191 & NA \\
\hline Individual (smooth) & - & - & - & 1.158 & 0.555 & 2.416 & NA \\
\hline Residual & - & - & - & 0.973 & 0.861 & 1.1 & NA \\
\hline
\end{tabular}



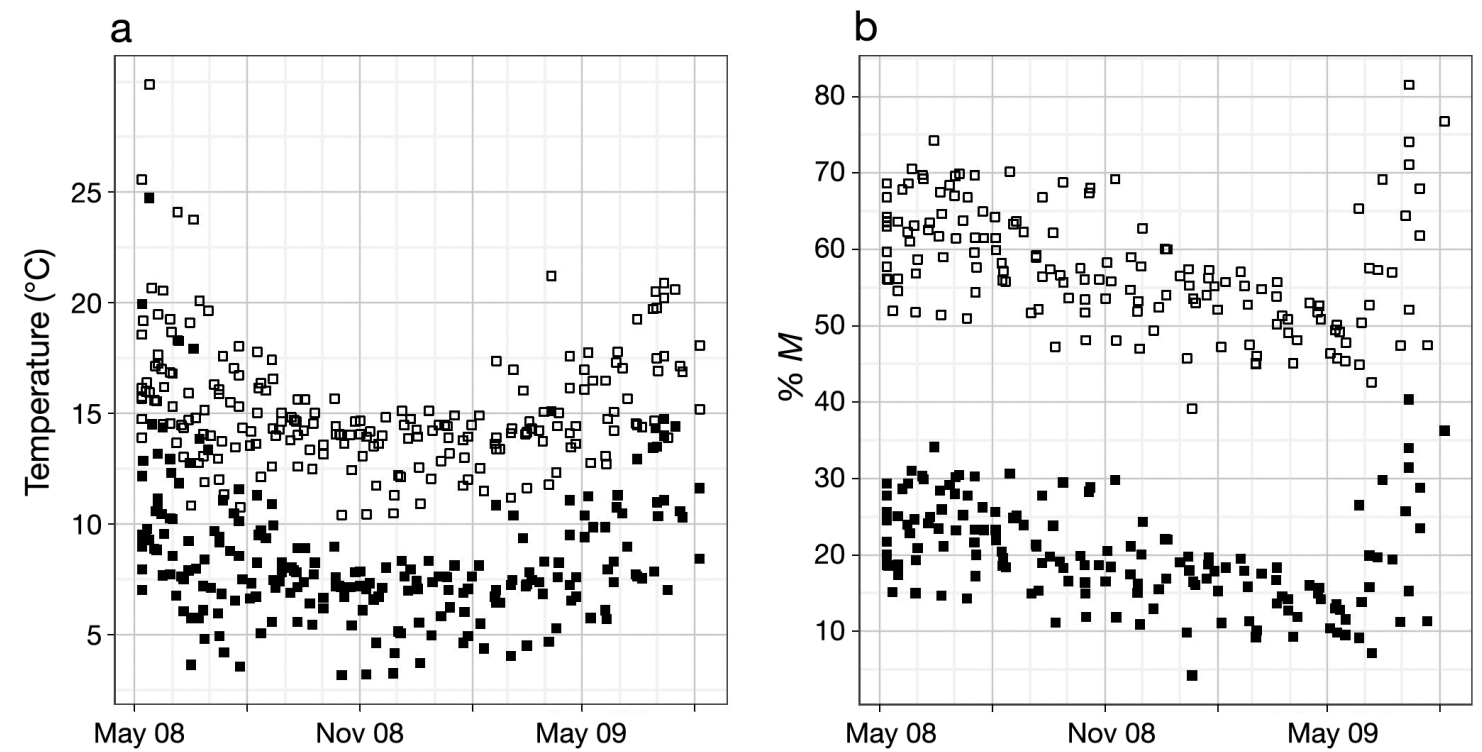

Fig. 6. Salmo salar. (a) Temperature $\left({ }^{\circ} \mathrm{C}\right.$ ) estimates calculated from pooled $1 \mathrm{SW}$ (see 'Introduction') Atlantic salmon $\delta^{18} \mathrm{O}_{\text {otolith }}$ values using equation parameters derived from the present data (solid squares) and from Storm-Suke et al. (2007) (open squares) and (b) upper and lower estimates of the proportion of metabolic carbon $(\% M)$ in the marine portion of wild Atlantic salmon otoliths. Values were calculated using measured $\delta^{13} \mathrm{C}_{\text {otolith }}$ values and the upper and lower values of a range of plausible values for $\delta^{13} \mathrm{C}_{\text {DIC }}(0$ to $2.2 \%)$, $\delta^{13} \mathrm{C}_{\text {diet }}\left(-23\right.$ to $-17.4 \%$ ) and $\varepsilon_{\text {total }}(-1.8$ to $2.7 \%$ o

derived equation and one generated from the present data for descriptive purposes.

That intra-otolith variability in marine $\delta^{18} \mathrm{O}$ exceeded among-individual variation suggests that 1SW Atlantic salmon thermal migratory behaviour is relatively constrained and that individuals experience broadly similar physical conditions at sea, perhaps to the extent that they actively choose to remain within surface waters of a relatively narrow thermal range (Friedland et al. 2000, Holm et al. 2000, Friedland \& Todd 2011). The majority of fish followed similar thermal trajectories; however, away from major surface currents and polar fronts, SST changes in the Norwegian Sea occur over large geographical distances so 2 fish with a similar thermal trajectory could have migrated to markedly different geographical areas. Fig. 6a shows the general curvilinear pattern of temperature history for all salmon combined, smoothed by estimated calendar date: fish moved from warm coastal waters following freshwater emigration to a range of perhaps $\sim 8$ to $10^{\circ} \mathrm{C}$ by late summer/early autumn, and reached the lowest temperature waters around November to February. They then gradually re-entered warmer waters the following spring, during their return migration.

The precise oceanic migratory path of 1SW Atlantic salmon is still under debate (Dadswell et al. 2010), but the general consensus is that post-smolts from southern Europe (British Isles, France, Spain) migrate north within the Continental Slope Current and Norwegian Coastal Current to reach the Norwegian Sea by July/August (Hansen \& Jacobsen 2000, Holst et al. 2000, Dadswell et al. 2010). 1SW salmon of southern European origin have been tagged both in the waters of the Norwegian Sea and north of the Faroe Islands in autumn and winter, suggesting these are important feeding areas (Hansen \& Jacobsen 2000, Holm et al. 2007). SST in this region during January ranges from $\sim 2$ to $10^{\circ} \mathrm{C}$ (Fig. 7). Whilst our chronology estimated from fish scales requires further confirmation, it is plausible that the general thermal profile described here is representative of salmon movement within the seasonal temperature range of the Norwegian Sea.

Notable differences exist among individuals that were not related to condition factor. The more variable $\delta^{18} \mathrm{O}$ values of A3 and B2 (Fig. 3) suggest that these fish periodically diverged from the common oceanic conditions. Such deviations may include excursions into colder regions of frontal or upwelling zones, indicated by higher $\delta^{18} \mathrm{O}$ otolith values. Individual B6 was particularly unusual in that the transition from freshwater to marine oxygen isotope values occurred gradually rather than in steps in this otolith. This may indicate that as a smolt, Fish B6 spent a prolonged period in an estuarine environment where water $\delta^{18} \mathrm{O}$ values tend to be lower in association with freshwater inputs. However, there also is the possibility that the transition was obscured by over-polishing the otolith section so that the SIMS transect did 


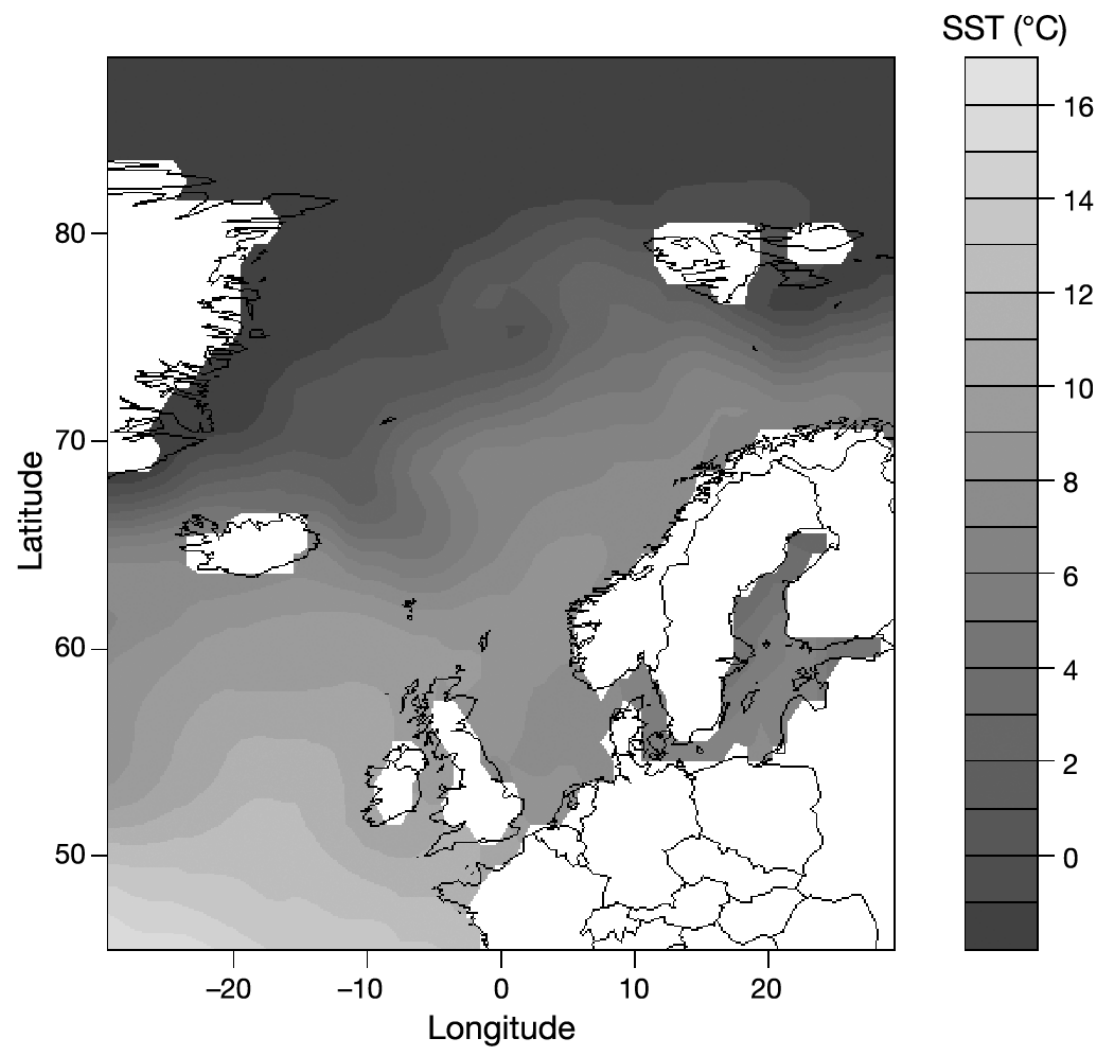

Fig. 7. Sea-surface temperature $\left(\mathrm{SST}_{i}{ }^{\circ} \mathrm{C}\right)$ range in the eastern North Atlantic during January 2009, compiled from the oiSSTv2 (Reynolds et al. 2002) dataset

not intersect the focus. Future studies using SIMS should consider alternative preparation techniques in order to reduce or constrain such errors.

The natal river stock of the sampled fish is unknown, as are the consequences of individual 'thermal strategies', indicated by $\delta^{18} \mathrm{O}$ pattern, for the general success and feeding/growth history of individual fish. Major, climate-driven, changes in eastern North Atlantic plankton communities have been well documented (Beaugrand et al. 2002, Beaugrand \& Reid 2003, Richardson \& Schoeman 2004). Particularly pertinent are the long-term declines in euphausiids and copepods-which are major constituents of Atlantic salmon and/or their forage fish diets (Jacobsen \& Hansen 2001, Haugland et al. 2006) —and northward shifts of cold-water copepod species. Whilst we can show no significant relationships between otolith $\delta^{18} \mathrm{O}$ and adult condition factor, the distribution of nekton (squid, forage fish) and zooplankton is patchy and constantly changing. Thus, whilst salmon might successfully locate areas of optimal temperatures, chance effects of plankton and nekton patchiness could render those areas suboptimal. Conversely, slight shifts in SST may reflect marked changes in prey availability and make the difference between salmon finding a productive feeding location, or essentially starving until higher quality areas are encountered. Uncertainty in otolith thermometry equations, as well as the small number of individuals analysed in the present study, could obscure notable differences related to condition factor. Notwithstanding these qualifications, our results suggest that the ultimate somatic condition of adult $1 \mathrm{SW}$ fish either of relatively high, or relatively low, $W_{\mathrm{r}}$ is not driven by large or systematic differences in thermal habitat selection. More likely, it is prey availability and quality that drive variation in adult condition.

\section{Metabolic/dietary histories}

The general pattern of the $\delta^{13} \mathrm{C}$ profile for all otoliths pooled (Fig. 5b) corresponds to similar curves reported in other studies (Gauldie 1996, Schwarcz et al. 1998, Høie et al. 2003, Wurster et al. 2005, Dufour et al. 2007). There was a large $(\sim 4 \%)$ ontogenetic increase in intraotolith $\delta^{13} \mathrm{C}$ values. Both the ontogenetic pattern and differences in otolith $\delta^{13} \mathrm{C}$ between individuals (Fig. 4) could be driven by (1) differences in the proportion of metabolically derived carbon $(M),(2)$ differences in $\delta^{13} C_{\text {diet }}$ values and/or (3) differences in $\delta^{13} C_{\text {DIC }}$ values. Possible sources of variability of these parameters include the diet, exposure to DIC and innate metabolism.

$$
\delta^{13} \mathrm{C}_{\text {diet }}
$$

Whilst Atlantic salmon are generalist, opportunistic, visual predators there is some evidence from stomach content analysis of ontogenetic changes in diet. In oceanic areas, the most common prey items of post-smolts are hyperiid amphipods, euphausiids and larval fish. Pre-adult salmon in the NE Atlantic include larger fish (e.g. sandeel, lanternfish, pearlsides) in their diets in addition to amphipods, euphausiids and other crustaceans (Hansen \& Pethon 1985, Jacobsen \& Hansen 2000, 2001, Haugland et al. 2006). $\delta^{13} \mathrm{C}_{\text {diet }}$ values for the potential prey of Atlantic salmon are poorly represented in the literature. However, 
average $\delta^{13} \mathrm{C}_{\text {diet }}$ values (after lipid extraction) of the important crustacean species (euphausiids, amphipods and copepods; mean $\pm \mathrm{SD}: \delta^{13} \mathrm{C}=-21.3 \pm 1.7 \%$ ) are approximately $3 \%$ lower than those of higher trophic level prey such as forage fish (sandeel, capelin, cod, haddock; $\delta^{13} \mathrm{C}=-18.2 \pm 0.8 \%$ ) (Sato et al. 2002, Møller 2006, Søreide et al. 2006). These differences probably result from trophic enrichment in ${ }^{13} \mathrm{C}$, which is close to $1 \%$ per trophic level in aquatic systems (Vander Zanden \& Rasmussen 2001). Thus, diet switching to larger, higher trophic level fish prey associated with rapid marine growth could account for some of the ontogenetic rise in $\delta^{13} \mathrm{C}$ values within salmon otoliths. It is noteworthy, however, that in some studies of otolith $\delta^{13} \mathrm{C}$, where $\delta^{13} \mathrm{C}$ of potential prey was measured, changes in diet were not sufficient to explain variation in otolith $\delta^{13} \mathrm{C}$ values (Høie et al. 2003, Dufour et al. 2007).

$$
\delta^{13} \mathrm{C}_{\text {DIC }}
$$

Spatial gradients in the carbon stable isotope value of marine DIC in surface waters are governed by a complex balance between biological and thermodynamic processes (Kroopnick 1985, Gruber et al. 1999). Variation in surface $\delta^{13} C_{\text {DIC }}$ is slight at midlatitudes, but high-latitude areas can show larger spatial and temporal fluctuations. In the northern North Atlantic, $\delta^{13} \mathrm{C}_{\text {DIC }}$ values can range seasonally by $\sim 1 \%$ at latitudes beyond $60^{\circ} \mathrm{N}$ (Gruber et al. 1999), largely owing to biological processes connected to summer stratification of surface waters. If this seasonal shift in $\delta^{13} \mathrm{C}_{\text {DIC }}$ were to account for variation in $\delta^{13} \mathrm{C}_{\text {otolith }}$ values, one would expect the latter to decrease as fish migrate throughout the summer and into winter. However, the trend was for an increase in $\delta^{13} \mathrm{C}_{\text {otolith }}$ values over this time from approximately -7 to $-5 \%$. Therefore, it is unlikely that changes in $\delta^{13} \mathrm{C}_{\mathrm{DIC}}$ can account for the pattern of $\delta^{13} \mathrm{C}_{\text {otolith }}$ values.

\section{Metabolic carbon}

In the absence of metabolic effects $(M=0)$ and assuming $\delta^{13} \mathrm{C}_{\text {DIC }}=1.65 \%$ o (intermediate between summer and winter values) and $\varepsilon_{\text {total }}$ between -1.8 and $-2.7 \%$ (Romanek et al. 1992, Solomon et al. 2006), $\delta^{13} \mathrm{C}_{\text {otolith }}$ should be approximately -1.65 to $-1.15 \%$, whereas measured $\delta^{13} \mathrm{C}_{\text {otolith }}$ generally was between -6 and $-8 \%$. Clearly, there is a metabolic contribution to the carbon pool from which $\delta^{13} \mathrm{C}_{\text {otolith }}$ values are derived. Estimates of $M$ vary widely across taxa and life stages (Solomon et al. 2006); however, where both $\delta^{13} \mathrm{C}_{\text {diet }}$ and $\delta^{13} \mathrm{C}_{\text {DIC }}$ have been measured (for juvenile fish only), $M$ ranges from 17 to $32 \%$ (Høie et al. 2003, Solomon et al. 2006). These estimates are specific to particular life stages, but, in reality, metabolic rate will fluctuate over the lifetime of an individual fish in response to the dynamics of temperature, growth and activity (Smith et al. 2009). A connection between otolith $\delta^{13} \mathrm{C}$ and fish bioenergetics has been established for several other species (Høie et al. 2003, Wurster \& Patterson 2003, Dufour et al. 2007), and it is likely that variation in metabolic activities over the period of rapid growth measured here in 1SW Atlantic salmon is a factor contributing to the ontogenetic and individual changes in otolith $\delta^{13} \mathrm{C}$. The nearly linear increase in $\delta^{13} \mathrm{C}$ values from smolt to adult life stages could reflect both a shift towards predominant piscivory and/or the decrease in metabolic rate with size.

Assuming that lower otolith $\delta^{13} \mathrm{C}$ values indicate an increased metabolic rate and/or diet shifts, the present findings indicate that fish experienced elevated metabolic rate(s) and/or diet changes primarily during the early phase of their marine migration, and also within the last few months prior to coastal return (Figs. 4b \& 5b). In a study of some of the physiological changes experienced by young Atlantic salmon as they move from rivers through estuaries and into the early marine phase, Stefansson et al. (2003) found evidence that post-smolts mobilize lipid reserves while conserving protein for somatic growth. This endogenous carbon contribution will be derived from a relatively ${ }^{13} \mathrm{C}$-depleted energy pool and could help explain the low otolith $\delta^{13} \mathrm{C}$ values early in the marine life stage. Additionally, the dietary $\mathrm{C}$ of younger and smaller salmon (e.g. the smaller constituents of the zooplankton size spectrum) is likely to be ${ }^{13} \mathrm{C}$-depleted, and would reinforce low otolith $\delta^{13} \mathrm{C}$ values during this stage. More incisive partitioning of otolith $\delta^{13} \mathrm{C}$ variability between metabolic and dietary influences would, however, necessitate highresolution, compound-specific amino acid isotope analysis (e.g. McMahon et al. 2011).

The decline in otolith $\delta^{13} \mathrm{C}$ over the last few months of the marine migration represents a marked departure from an ontogenetically based decline in metabolic rate with fish size. It is unlikely to be due to a rapid diet switch because homing salmon are known to cease or markedly reduce feeding during this time (Jacobsen \& Hansen 2000). All fish used in this study had empty guts upon capture in coastal waters, and, during the homing period, salmon are particularly 
active. Physiological changes associated with preparation for reproduction and freshwater re-entry could increase metabolic rate and hence the proportion of dietary carbon. Limited dietary intake during this period means that otolith carbon would be derived not from newly assimilated dietary items, but from catabolic processes affecting lipid reserves - which themselves represent a relatively ${ }^{13} \mathrm{C}$-depleted carbon pool (DeNiro \& Epstein 1977). Thus, we suggest that homing Atlantic salmon begin catabolising crucial lipid reserves immediately prior to freshwater re-entry.

There was no evidence that fish returning in poor growth condition had experienced significantly different metabolic histories from those returning in normal to high condition, although there are obvious individual differences in otolith $\delta^{13} \mathrm{C}$ values. Three fish (A2, A3, B6; Fig. 4) did not show a rapid decrease in the final otolith $\delta^{13} \mathrm{C}$ values. It is possible that these individuals were en route to more southerly rivers and had not yet begun the physiological changes necessary for freshwater spawning migration.

The high-resolution profiles found in the present study allow detailed comparisons of $\delta^{18} \mathrm{O}$ and $\delta^{13} \mathrm{C}$ between and within individuals during comparable periods of their marine migration. The ability to retrospectively study entire marine life histories of individual fish that survive to complete the marine migration is presently limited to stable isotope analyses of otoliths. Most contemporary biotelemetry technologies do not allow for long-term deployment or retrieval of tags throughout the marine phase, and traditional tags have an extremely low probability of retrieval for Atlantic salmon. There was no evidence from our analyses that adults returning in poor condition had migrated to warmer areas of the eastern North Atlantic, but the current limitations in otolith thermometry for wild, free-ranging marine fish are substantial. It appears likely that Scottish salmon ultimately returning, both in good and poor condition, continue to migrate to areas of the Norwegian Sea with appropriate temperatures, but most individuals still fail to encounter optimal prey availability. Thus, the present results support the conclusions of Todd et al. (2008), who asserted that Scottish 1SW salmon are encountering climate-associated changes in prey availability over wide areas of the Norwegian Sea. Intra-otolith $\delta^{13} \mathrm{C}$ values can be informative of the metabolic and dietary history of individual fish, and indicate a striking period of physiological stress and potential lipid catabolism in the last months of marine migration. Notwithstanding the limitations that retrospective estimates suffer due to a great deal of uncer- tainly in parameter coefficients, a fuller understanding of the trophic and metabolic consequences of ocean migration can be derived from high-resolution SIMS data for individual otoliths and such may prove invaluable in predicting the likely implications of future climate change on salmon at sea.

Acknowledgements. Funding for this research was provided by a University of St Andrews Overseas Research Student Award, the Natural Environment Research Council (Ion Microprobe Facility Project Grant 383/1109) and the Atlantic Salmon Trust. We thank J. Salkeld for donating the salmon samples to the study. We also are grateful to M. Hall (University of Edinburgh) for assistance with sample preparation, M. Lonergan for statistical advice and A. Calder (University of St Andrews) for mineralogical advice and assistance with XRD analysis.

\section{LITERATURE CITED}

Akaike H (1976) An information criterion (AIC). Math Sci 14: $5-9$

Anonymous (2010) Report of the working group on North Atlantic salmon (WGNAS). ICES CM 2010/ACOM:09, International Council for the Exploration of the Sea, Copenhagen

Bacon PJ, Palmer SCF, MacLean JC, Smith GW, Whyte BDM, Gurney WSC, Youngson AF (2009) Empirical analyses of the length, weight, and condition of adult Atlantic salmon on return to the Scottish coast between 1963 and 2006. ICES J Mar Sci 66:844-859

Beaugrand G, Reid PC (2003) Long-term changes in phytoplankton, zooplankton and salmon related to climate. Glob Change Biol 9:801-817

> Beaugrand G, Reid PC, Ibañez F, Lindley JA, Edwards M (2002) Reorganization of North Atlantic marine copepod biodiversity and climate. Science 296:1692-1694

> Blackwell BG, Brown ML, Willis DW (2000) Relative weight $\left(W_{\mathrm{r}}\right)$ status and current use in fisheries assessment and management. Rev Fish Sci 8:1-44

Campana SE (1999) Chemistry and composition of fish otoliths: pathways, mechanisms and applications. Mar Ecol Prog Ser 188:263-297

Campana SE, Thorrold SR (2001) Otoliths, increments, and elements: Keys to a comprehensive understanding of fish populations? Can J Fish Aquat Sci 58:30-38

Coplen TB (1996) New guidelines for reporting stable hydrogen, carbon, and oxygen isotopre-ratio data. Geochim Cosmochim Acta 60:3359-3360

Coplen TB, Kendall C, Hopple J (1983) Comparison of stable isotope reference samples. Nature 302:236-238

> Dadswell MJ, Spares AD, Reader JM, Stokesbury MJW (2010) The North Atlantic subpolar gyre and the marine migration of Atlantic salmon Salmo salar: the 'Merry-GoRound' hypothesis. J Fish Biol 77:435-467

> Degens ET, Deuser WG, Haedrich RL (1969) Molecular structure and composition of fish otoliths. Mar Biol 2: 105-113

Dempson JB, Braithwaite VA, Doherty D, Power M (2009) Stable isotope analysis of marine feeding signatures of Atlantic salmon in the North Atlantic. ICES J Mar Sci 67:52-61 
DeNiro MJ, Epstein S (1977) Mechanism of carbon isotope fractionation associated with lipid synthesis. Science 197: 261-263

> Dufour E, Gerdeaux D, Wurster CM (2007) Whitefish (Coregonus lavaretus) respiration rate governs intra-otolith variation in $\delta^{13} \mathrm{C}$ values in Lake Annecy. Can J Fish Aquat Sci 64:1736-1746

> Dufour E, Hook TO, Patterson WP, Rutherford ES (2008) High-resolution isotope analysis of young alewife Alosa pseudoharengus otoliths: assessment of temporal resolution and reconstruction of habitat occupancy and thermal history. J Fish Biol 73:2434-2451

> Frew RD, Dennis PF, Heywood KJ, Meredith MP, Boswell SM (2000) The oxygen isotope composition of water masses in the northern North Atlantic. Deep-Sea Res I 47:2265-2286

Friedland KD, Todd CD (2012) Changes in northwest Atlantic arctic and subarctic conditions and the growth response of Atlantic salmon. Polar Biol 35:593-609

> Friedland KD, Hansen LP, Dunkley DA, MacLean JC (2000) Linkage between ocean climate, post-smolt growth, and survival of Atlantic salmon (Salmo salar L.) in the North Sea area. ICES J Mar Sci 57:419-429

Friedland KD, MacLean JC, Hansen LP, Peyronnet AJ and others (2009) The recruitment of Atlantic salmon in Europe. ICES J Mar Sci 66:289-304

> Gao YW, Beamish RJ (1999) Isotopic composition of otoliths as a chemical tracer in population identification of sockeye salmon Oncorhynchus nerka. Can J Fish Aquat Sci 56:2062-2068

Gauldie RW (1996) Biological factors controlling the carbon isotope record in fish otoliths: principles and evidence. Comp Biochem Physiol B 115:201-208

Geffen AJ (1983) The deposition of otolith rings in Atlantic salmon, Salmo salar L., embryos. J Fish Biol 23:467-474

> Godbout L, Trudel M, Irvine JR, Wood CC, Grove MJ, Schmitt AK, McKeegan KD (2010) Sulfur isotopes in otoliths allow discrimination of anadromous and nonanadromous ecotypes of sockeye salmon (Oncorhynchus nerka). Environ Biol Fishes 89:521-532

> Godbout L, Wood CC, Withler RE, Latham S and others (2011) Sockeye salmon (Oncorhynchus nerka) return after an absence of nearly 90 years: a case of reversion to anadromy. Can J Fish Aquat Sci 68:1590-1602

Gruber N, Keeling CD, Bacastow RB, Guenther P and others (1999) Spatiotemporal patterns of carbon-13 in the global surface oceans and the oceanic Suess effect. Global Biogeochem Cycles 13:307-335

Hansen LP, Jacobsen JA (2000) Distribution and migration of Atlantic salmon, Salmo salar L., in the sea. In: Mills D (ed) The ocean life of Atlantic salmon: environmental and biological factors influencing survival. Fishing News Books, Oxford, p 75-87

Hansen LP, Pethon P (1985) The food of Atlantic salmon, Salmo salar L., caught by long-line in northern Norwegian waters. J Fish Biol 26:553-562

Hanson NN, Wurster CM, EIMF, Todd CD (2010) Comparison of secondary ion mass spectrometry and micromilling/continuous flow isotope ratio mass spectrometry techniques used to acquire intra-otolith $\delta^{18} \mathrm{O}$ values of wild Atlantic salmon (Salmo salar). Rapid Commun Mass Spectrom 24:2491-2498

Haugland M, Holst JC, Holm M, Hansen LP (2006) Feeding of Atlantic salmon (Salmo salar L.) post-smolts in the Northeast Atlantic. ICES J Mar Sci 63:1488-1500
Heidarsson T, Antonsson T, Snorrason S (2006) The relationship between body and scale growth proportions and validation of two back-calculation methods using individually tagged and recaptured wild Atlantic salmon. Trans Am Fish Soc 135:1156-1164

Høie H, Folkvord A, Otterlei E (2003) Effect of somatic and otolith growth rate on stable isotopic composition of early juvenile cod (Gadus morhua L) otoliths. J Exp Mar Biol Ecol 289:41-58

> Høie H, Andersson C, Folkvord A, Karlsen Ø (2004a) Precision and accuracy of stable isotope signals in otoliths of pen-reared cod (Gadus morhua) when sampled with a high-resolution micromill. Mar Biol 144:1039-1049

Høie H, Otterlei E, Folkvord A (2004b) Temperature-dependent fractionation of stable oxygen isotopes in otoliths of juvenile cod (Gadus morhua L.). ICES J Mar Sci 61: 243-251

> Holm M, Holst JC, Hansen LP (2000) Spatial and temporal distribution of post-smolts of Atlantic salmon (Salmo salar L.) in the Norwegian Sea and adjacent areas. ICES J Mar Sci 57:955-964

Holm M, Hoist JC, Hansen LP, Jacobsen JA, O'Maoileidigh N, Moore A (2007) Migration and distribution of Atlantic salmon post-smolts in the North Sea and north-east Atlantic. In: Mills D (ed) Salmon at the edge. Blackwell Science, Oxford, p 5-23

Holst JC, Shelton R, Holm M, Hansen LP (2000) Distribution and possible migration routes of post-smolt Alantic salmon in the north-east Atlantic. In: Mills D (ed) The ocean life of Atlantic salmon: environmental and biological factors influencing survival. Fishing News Books, Oxford, p 65-74

Hurvich CM, Tsai CL (1989) Regression and time series model selection in small samples. Biometrika 76:297-307

ICES (International Council for the Exploration of the Sea) (2008) Report of the working group on North Atlantic salmon (WGNAS). ICES, Galway

ICES (International Council for the Exploration of the Sea) (2010) Report of the working group on North Atlantic salmon (WGNAS). ICES, Copenhagen

Jacobsen JA, Hansen LP (2000) Feeding habits of Atlantic salmon at different life stages at sea. In: Mills D (ed) The ocean life of Atlantic salmon: environmental and biological factors influencing survival. Fishing News Books, Oxford, p 170-192

Jacobsen JA, Hansen LP (2001) Feeding habits of wild and escaped farmed Atlantic salmon, Salmo salar L., in the Northeast Atlantic. ICES J Mar Sci 58:916-933

Jakupsstovu SHI, Mills D, Piggins D (1988) Exploitation and migration of salmon in Faroese waters. In: Mills DH, Piggins DJ (eds) Atlantic salmon: planning for the future. Croom Helm, London, p 458-482

Jensen A, Fiske P, Hansen L, Johnsen B, Mork K, Næsje T (2011) Synchrony in marine growth among Atlantic salmon (Salmo salar) populations. Can J Fish Aquat Sci 68:444-457

> Johnson RC, Weber PK, Wikert JD, Workman ML, MacFarlane RB, Grove MJ, Schmitt AK (2012) Managed metapopulations: Do salmon hatchery 'sources' lead to inriver 'sinks' in conservation? PLoS ONE 7:e28880

- Kalish JM (1991a) ${ }^{13} \mathrm{C}$ and ${ }^{18} \mathrm{O}$ isotopic disequilibria in fish otoliths: metabolic and kinetic effects. Mar Ecol Prog Ser 75:191-203

Kalish JM (1991b) Oxygen and carbon stable isotopes in the otoliths of wild and laboratory-reared Australian salmon (Arripis trutta). Mar Biol 110:37-47 
Kim ST, O'Neil JR, Hillaire-Marcel C, Mucci A (2007) Oxygen isotope fractionation between synthetic aragonite and water: influence of temperature and $\mathrm{Mg}^{2+}$ concentration. Geochim Cosmochim Acta 71:4704-4715

Kroopnick PM (1985) The distribution of ${ }^{13} \mathrm{C}$ of $\Sigma \mathrm{CO}_{2}$ in the world oceans. Deep-Sea Res 32:57-84

> LeGrande AN, Schmidt GA (2006) Global gridded data set of the oxygen isotopic composition in seawater. Geophys Res Lett 33:L12604, doi:10.1029/2006GL026011

MacKenzie KM, Palmer MR, Moore A, Ibbotson AT, Beaumont WRC, Poulter DJS, Trueman CN (2011) Locations of marine animals revealed by carbon isotopes. Scientific Reports 1, Article 21, published by MacMillan Publishers, available at: www.nature.com/srep/2011/110623/srep 00021/full/srep00021.html

McMahon KW, Fogel ML, Johnson BJ, Houghton LA, Thorrold SR (2011) A new method to reconstruct fish diet and movement patterns from $\delta^{13} \mathrm{C}$ values in otolith amino acids. Can J Fish Aquat Sci 68:1330-1340

Møller P (2006) Lipids and stable isotopes in marine food webs in West Greenland: trophic relations and health implications. PhD dissertation, Technical University of Denmark, Lyngby

Mulcahy SA, Killingley JS, Phleger CF, Berger WH (1979) Isotopic composition of otoliths from a benthopelagic fish, Coryphaenoides acrolepis Macrouridae: Gadiformes. Oceanol Acta 2:423-427

> Murayama E, Takagi Y, Ohira T, Davis JG, Greene MI, Nagasawa H (2002) Fish otolith contains a unique structural protein, otolin-1. Eur J Biochem 269:688-696

Patterson W, Smith G, Lohmann K (1993) Continental paleothermometry and seasonality using the isotopic composition of aragonitic otoliths of freshwater fishes. In: Swart JK, Lohmann KC, McKenzie JA, Savin S (eds) Climate change in continental isotopic records, Vol 78. AGU, Washington, DC, p 191-202

Popper AN, Coombs S (1982) The morphology and evolution of the ear in Actinopterygian fishes. Am Zool 22:311-328

Popper AN, Lu Z (2000) Structure-function relationships in fish otolith organs. Fish Res 46:15-25

R Core Development Team (2011) R: a language and environment for statistical computing. R Foundation for Statistical Computing, Vienna

Reynolds RW, Rayner NA, Smith TM, Stokes DC, Wang W (2002) An improved in situ and satellite SST analysis for climate. J Clim 15:1609-1625

Richardson AJ, Schoeman DS (2004) Climate impact on plankton ecosystems in the northeast Atlantic. Science 305:1609-1612

Rikardsen AH, Dempson JB (2011) Dietary life-support: the food and feeding of Atlantic salmon at sea. In: Aas $\varnothing$, Einum S, Klemetsen A, Skurdal J (eds) Atlantic salmon ecology. Wiley-Blackwell, London

Romanek CS, Grossman EL, Morse JW (1992) Carbon isotopic fractionation in synthetic aragonite and calcite: effects of temperature and precipitation rate. Geochim Cosmochim Acta 56:419-430

Sato M, Sasaki H, Fukuchi M (2002) Stable isotopic compositions of overwintering copepods in the arctic and subarctic waters and implications to the feeding history. J Mar Sci 38:165-174

Schmidt GA, Bigg GR, Rohling EJ (1999) Global seawater oxygen-18 database, v1.21. Available at: www.giss.nasa. gov/data/o18data

Schwarcz HP, Gao Y, Campana S, Browne D, Knyf M, Brand
U (1998) Stable carbon isotope variations in otoliths of Atlantic cod (Gadus morhua). Can J Fish Aquat Sci 55: 1798-1806

Shearer W (1986) The exploitation of Atlantic salmon in Scottish home water fisheries in 1952-83. In: Jenkins D, Shearer W (eds) The status of the Atlantic salmon in Scotland. Institute of Terrestrial Ecology, Abbots Ripton, p 7-49

Shearer WM (1992) Atlantic salmon scale reading guidelines. International Council for the Exploration of the Sea, Copenhagen

> Sherwood GD, Rose GA (2003) Influence of swimming form on otolith $\delta^{13} \mathrm{C}$ in marine fish. Mar Ecol Prog Ser 258: 283-289

Sinnatamby RN, Dempson JB, Chaput G, Caron F, Niemelä E, Erkinaro J, Power M (2009) Spatial and temporal variability in the trophic ecology of Atlantic salmon in the North Atlantic inferred from analyses of stable isotope signatures. In: Haro A, Smith KL, Rulifson RA, Moffitt $\mathrm{CM}$ and others (eds) Challenges for diadromous fishes in a dynamic global environment. American Fisheries Society, Bethesda, MD, p 447-463

> Smith IP, Booker DJ, Wells NC (2009) Bioenergetic modelling of the marine phase of Atlantic salmon (Salmo salar L.). Mar Environ Res 67:246-258

Solomon CT, Weber PK, Jr JJC, Ingram BL and others (2006) Experimental determination of the sources of otolith carbon and associated isotopic fractionation. Can J Fish Aquat Sci 63:79-89

Søreide JE, Hop H, Carroll ML, Falk-Petersen S, Hegseth EN (2006) Seasonal food web structures and sympagic-pelagic coupling in the European Arctic revealed by stable isotopes and a two-source food web model. Prog Oceanogr 71:59-87

Stefansson SO, Bjornsson BT, Sundell K, Nyhammer G, McCormick SD (2003) Physiological characteristics of wild Atlantic salmon post-smolts during estuarine and coastal migration. J Fish Biol 63:942-955

Storm-Suke A, Dempson JB, Reist JD, Power M (2007) A field-derived oxygen isotope fractionation equation for Salvelinus species. Rapid Commun Mass Spectrom 21: 4109-4116

> Thorrold SR, Campana SE, Jones CM, Swart PK (1997) Factors determining $\delta^{13} \mathrm{C}$ and $\delta^{18} \mathrm{O}$ fractionation in aragonitic otoliths of marine fish. Geochim Cosmochim Acta 61: 2909-2919

Todd CD Friedland K, MacLean JC, Whyte BD, Russell IC, Lonergan ME, Morrissey MB (2012) Phenological and phenotypic changes in Atlantic salmon populations in response to a changing climate. ICES J Mar Sci 69(9): 1686-1698

Todd CD, Hughes SL, Marshall CT, MacLean JC, Lonergan ME, Biuw EM (2008) Detrimental effects of recent ocean surface warming on growth condition of Atlantic salmon. Glob Change Biol 14:958-970

Tohse H, Mugiya Y (2004) Sources of carbonate in fish otoliths: incorporation from bicarbonate and glucose. In: Kobayashi I, Ozawa H (eds) Biomineralization: formation, diversity, evolution and application. Tokai University Press, Tokyo

Trueman CN, Moore A (2007) Use of stable isotope composition of fish scales for monitoring aquatic ecosystems. In: Dawson TE, Siegwolf RTW (eds) Stable isotopes as indicators of ecological change. Elsevier Inc, London, p 145-162 
Vander Zanden MJ, Rasmussen JB (2001) Variation in $\delta^{15} \mathrm{~N}$ and $\delta^{13} \mathrm{C}$ trophic fractionation: implications for aquatic food web studies. Limnol Oceanogr 46:2061-2066

Wankowski JWJ (1977) The role of prey size in the feeding behaviour and growth of juvenile Atlantic salmon (Salmo salar L.). PhD dissertation, University of Stirling, Stirling

- Weidel BC, Ushikubo T, Carpenter SR, Kita NT and others (2007) Diary of a bluegill (Lepomis macrochirus): daily $\delta^{13} \mathrm{C}$ and $\delta^{18} \mathrm{O}$ records in otoliths by ion microprobe. Can J Fish Aquat Sci 64:1641-1645

Wells BK, Friedland KD, Clarke LM (2003) Increment patterns in otoliths and scales from mature Atlantic salmon Salmo salar. Mar Ecol Prog Ser 262:293-298

Wood S (2011) mgcv: GAMs with GCV/AIC/REML smoothness estimation and GAMMs by PQL. Available at http:// cran.r-project.org/package $=\mathrm{mgcv}$

- Wright PJ, Rowe D, Thorpe JE (1991) Daily growth incre-

Editorial responsibility: Yves Cherel,

Villiers-en-Bois, France ments in the otoliths of Atlantic salmon parr, Salmo salar L., and the influence of environmental factors on their periodicity. J Fish Biol 39:103-113

Wurster CM, Patterson WP (2003) Metabolic rate of late Holocene freshwater fish: evidence from $\delta^{13} \mathrm{C}$ values of otoliths. Paleobiology 29:492-505

> Wurster CM, Patterson WP, Stewart DJ, Bowlby JN, Stewart TJ (2005) Thermal histories, stress, and metabolic rates of chinook salmon (Oncorhynchus tshawytscha) in Lake Ontario: evidence from intra-otolith stable isotope analyses. Can J Fish Aquat Sci 62:700-713

Zazzo A, Smith GR, Patterson WP, Dufour E (2006) Life history reconstruction of modern and fossil sockeye salmon (Oncorhynchus nerka) by oxygen isotopic analysis of otoliths, vertebrae, and teeth: implication for paleoenvironmental reconstructions. Earth Planet Sci Lett 249: 200-215

Submitted: January 4, 2012; Accepted: September 19, 2012 Proofs received from author(s): February 1, 2013 